\title{
Holes U1415K, U1415L, U1415M, and U1415N'
}

K.M. Gillis, J.E. Snow, A. Klaus, G. Guerin, N. Abe, N. Akizawa, G. Ceuleneer, M.J. Cheadle, Á. Adrião, K. Faak, T.J. Falloon, S.A. Friedman, M.M. Godard, Y. Harigane, A.J. Horst, T. Hoshide, B. Ildefonse, M.M. Jean, B.E. John, J.H. Koepke, S. Machi, J. Maeda, N.E. Marks, A.M. McCaig, R. Meyer, A. Morris, T. Nozaka, M. Python, A. Saha, and R.P. Wintsch²

\section{Chapter contents}

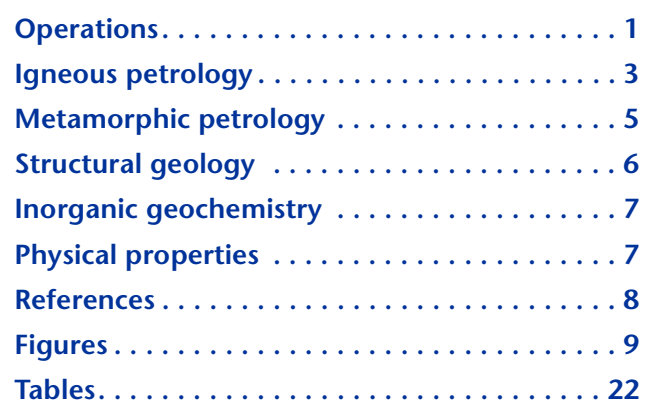

${ }^{1}$ Gillis, K.M., Snow, J.E., Klaus, A., Guerin, G., Abe, N., Akizawa, N., Ceuleneer, G., Cheadle, M.J., Adrião, Á., Faak, K., Falloon, T.J., Friedman, S.A., Godard, M.M., Harigane, Y., Horst, A.J., Hoshide, T., Ildefonse, B., Jean, M.M., John, B.E., Koepke, J.H., Machi, S., Maeda, J., Marks, N.E., McCaig, A.M., Meyer, R., Morris, A., Nozaka, T., Python, M., Saha, A., and Wintsch, R.P., 2014. Holes U1415K, U1415L, U1415M, and U1415N. In Gillis, K.M., Snow, J.E., Klaus, A., and the Expedition 345 Scientists, Proc. IODP, 345: College Station, TX (Integrated Ocean Drilling Program). doi:10.2204/iodp.proc.345.111.2014

'Expedition 345 Scientists' addresses.

\section{Operations}

Integrated Ocean Drilling Program (IODP) Holes U1415K$\mathrm{U} 1415 \mathrm{~N}$ were sited on a small bench $\sim 200 \mathrm{~m}$ shallower than the main target area (see Fig. F8 in the "Expedition 345 summary" chapter [Gillis et al., 2014b]). This was done in order to exploit and test a geologic model whereby the small bench was the top of a headwall scarp and would expose a more competent formation. Hole U1415K attempted to establish a hole with reentry capability penetrating to 35.3 meters below seafloor (mbsf) without any coring except for a single ghost core (345-U1415K-2G) that recovered $4.72 \mathrm{~m}$ of surficial mud, gravel, and rocks. Hole U1415L consisted of a jet-in to 4 mbsf; no cores were recovered. Hole U1415M was a failed attempt to establish reentry capability that penetrated to 25.9 mbsf without any coring except for a single ghost core (345-U1415M-2G) containing $5.87 \mathrm{~m}$ of surface gravel and mud. Hole U1415N consisted of rotary core barrel (RCB) coring that penetrated to $37.0 \mathrm{mbsf}$ and recovered a total of $1.56 \mathrm{~m}(4 \%)$ of olivine-phyric basalt and gabbro. Hole operations are summarized in Table T1 and outlined below. All times are ship local time (UTC $-7 \mathrm{~h})$.

\section{Hole U1415K drilling operations}

After moving to the small bench site $\sim 400 \mathrm{~m}$ northwest of Hole U1415J, we lowered a new bottom-hole assembly (BHA) with a $143 / 4$ inch tri-cone bit to the seafloor and prepared to conduct a short camera survey prior to spudding the hole. However, the camera developed problems during the trip in and had to be recovered. A spare camera was installed before the BHA was redeployed. We conducted an expanding box survey extending out 10 $\mathrm{m}$, and a location to start Hole U1415K was chosen. We verified the seafloor depth (4698.4 meters below rig floor [mbrf]) by tagging the seafloor with the bit, retrieved the camera system, and started Hole U1415K at $2155 \mathrm{~h}$ on 16 January 2013 . The $143 / 4$ inch hole reached a total depth of 35.3 mbsf by $0400 \mathrm{~h}$ on 17 January. A wiper trip was performed, and the bit was pulled back to 6.6 mbsf. A 16 inch free-fall funnel (FFF) without any stinger was deployed to facilitate subsequent reentries. The driller waited $1.25 \mathrm{~h}$ before pulling out of the hole to allow time for the FFF to reach the seafloor. The bit was then pulled clear of the seafloor at 2310 $\mathrm{h}$ on 17 January. We deployed the camera to observe the FFF cone; the cone was not upright and appeared to be nearly on its 
side. We felt that the base of the FFF cone was still in or immediately adjacent to the hole. We decided to retrieve the bit, change to an $\mathrm{RCB} B H A$, and attempt to reenter the hole (either through the FFF cone or by a bare rock reentry). The ultimate goal was to deploy a second FFF with $103 / 4$ inch casing to stabilize the upper $\sim 35 \mathrm{~m}$ of hole and allow deeper coring. The $143 / 4$ inch bit arrived back on the rig floor at $1110 \mathrm{~h}$ on 18 January. A $36 \mathrm{~m}$ length of $103 / 4$ inch casing string was assembled and hung off in the moonpool doors using C-plates and casing elevators. The RCB BHA was assembled and lowered through the casing and back to the seafloor. The camera was deployed, and a seafloor survey was conducted from $2333 \mathrm{~h}$ on 18 January until $0051 \mathrm{~h}$ on 19 January in an attempt to locate Hole U1415K. No discernible hole or cuttings mound could be identified during the survey, and it was decided that the hole was located at the base of the leaning FFF cone. A reentry was attempted by placing the bit at the base of the cone. This was accomplished relatively quickly $(\sim 45$ $\mathrm{min}$ ) and the bit was lowered into the seafloor, penetrating 1-2 $\mathrm{m}$ before taking weight. We decided to retrieve the camera and to attempt to walk the bit into the hole using light bit weight and low rpm. A perceived reentry into Hole U1415K occurred at $0140 \mathrm{~h}$. Rotation was applied for $\sim 2 \mathrm{~h}$ without any luck in penetrating further into the hole. We decided to abandon our attempts to continue operations in Hole U1415K, retrieve the RCB BHA, and start a new hole with a $143 / 4$ inch tri-cone bit. We recovered the core barrel that was in place during the attempt to reenter Hole U1415K (Core 2G; 0 to 0.5 mbsf; $4.72 \mathrm{~m}$ recovered) and then retrieved the RCB BHA. The RCB BHA and coring bit was back on the rig floor at 1510 $\mathrm{h}$ on 19 January. The seafloor positioning beacon deployed at the start of our Hess Deep operations on 22 December 2012 was nearing the expected lifetime of its batteries, so we commanded it to release at $1503 \mathrm{~h}$ and it was back aboard at $1639 \mathrm{~h}$ on 19 January.

\section{Hole U1415L drilling operations}

We assembled a 143/4 inch tri-cone bit and drilling BHA with three stands of drill collars and lowered it to the seafloor. While the BHA was being lowered, we also deployed the camera system with the same positioning beacon (with new batteries) and the 3.5 $\mathrm{kHz}$ pinger. The seafloor positioning beacon was commanded to release at the Hole U1415K coordinates, but it did not immediately fall to the seafloor. After 40 mines of working the camera system up and down, the beacon eventually came loose. At $0515 \mathrm{~h}$ on 20 January 2013, we started a visual and $3.5 \mathrm{kHz}$ subbottom seafloor survey by moving the ship $95 \mathrm{~m}$ east of Hole U1415K (see Table T1 and Fig. F3 in the
"Bench site survey" chapter [Gillis et al., 2014a]). Unfortunately, the $3.5 \mathrm{kHz}$ pinger ceased working before the survey commenced, but we continued with the visual inspection of the seafloor. After we arrived at the target location, we conducted a box survey extending out $10 \mathrm{~m}$ to ensure that no large boulders or rubble were in close proximity. We also tagged the seafloor with the bit, revealing an approximate seafloor slope of $\sim 14^{\circ}$ to the south. Hole U1415L consisted of a $1 \mathrm{~h}$ jet-in test that penetrated to $4 \mathrm{mbsf}$ through sediment and soft rubble. Hole U1415L was spudded at $0845 \mathrm{~h}$ on 20 January, and the bit was pulled clear of the seafloor at $0900 \mathrm{~h}$.

\section{Hole U1415M drilling operations}

After recovering the camera system, Hole U1415M was started at $1240 \mathrm{~h}$ on 20 January 2013 . The initial penetration from seafloor to 5 mbsf went relatively quickly, indicating that the formation was sediment/ soft rubble. From $\sim 5$ to 9 mbsf, the formation became hard with a significantly slower rate of penetration (ROP; $0.5-1.0 \mathrm{~m} / \mathrm{h}$ ) and smooth torque, as is typical of massive hard rock. The ROP increased again to $\sim 4.0 \mathrm{~m} / \mathrm{h}$ from 9.0 to $11.0 \mathrm{mbsf}$. A hard rock reentry system-style FFF with a 26 inch opening was assembled around the drill string in the moonpool. We did not attach a stinger or base plate. The funnel was deployed at $2100 \mathrm{~h}$ on 20 January. We then deepened the hole to $19.6 \mathrm{mbsf}$, where the hole began to pack off. We spent the next $4 \mathrm{~h}$ washing and reaming the hole and circulating high-viscosity mud. Eventually the hole was stabilized, and we continued drilling to 25.9 mbsf. At that depth, the bottom of the hole became problematic and the bit was unable to penetrate deeper than 24 mbsf, so we conducted a wiper trip by raising the bit to $8 \mathrm{mbsf}$ and then lowering it to the bottom of the hole. However, the bit still could not penetrate past 24 mbsf. Another high-viscosity mud sweep was pumped. The camera system was lowered to observe the orientation of the FFF cone, but it was obscured by clouds of mud and cuttings coming from the hole. Portions of the rim of the FFF cone, however, were discernible at times buried in cuttings. We pulled the bit out of the hole at $1602 \mathrm{~h}$ on 21 January and then waited for $1 \mathrm{~h}$ to let cuttings settle for better visibility. The top of the FFF cone was clearly visible in the cuttings mound. The camera was retrieved, the drill string raised to 4660 mbrf, the top drive set back, and we performed a slip and cut of $115 \mathrm{ft}$ of drill line. After the slip and cut, the drill string was recovered, and the bit arrived back on the rig floor at $0330 \mathrm{~h}$ on 22 January. Our next step was to assemble $25 \mathrm{~m}$ of $10^{3 / 4}$ inch casing and hang it off on the moonpool doors. We assembled a RCB BHA with a used C-7 core bit (2 
h rotating time in Hole $\mathrm{U} 1415 \mathrm{~K})$ and lowered it and the camera system to the seafloor. The top drive was installed and the drill string spaced out for reentry into Hole U1415M. An attempt was made to maneuver the vessel for reentry; however, because of the drill string space out, the bit was positioned nearly at the seafloor, and the driller was unable to raise the bit any higher. This resulted in the bit repeatedly tagging the cuttings mound and the FFF, creating clouds of debris in the water column and completely obscuring the FFF cone. We offset the ship south to slightly deeper water while a $30 \mathrm{ft}$ knobby was laid out and a $20 \mathrm{ft}$ knobby was picked up, giving an additional $3 \mathrm{~m}$ of room in the derrick. We moved back over Hole U1415M and reentered the FFF cone at $1645 \mathrm{~h}$ on 22 January. The cone appeared to tip/shift as the bit made contact with the inner surface. Circulation along with slow rotation was used in an unsuccessful attempt to find the $14 \%$ inch hole. No progress was made, and we retrieved the camera system so we could use more rotation. This also was not successful, so we redeployed the camera system and offset the ship in an attempt to drag the funnel out of the way. This also did not work, and the FFF cone appeared to be solidly in place in the cuttings mound, wedged sideways into a large boulder that had been hidden beneath the seafloor sediment. We reentered the FFF cone for one last failed attempt to find the hole below the FFF cone. We then decided to abandon Hole U1415M at 0000 h on 23 January. Ghost Core 2G (assumed to be from 0 to $3.5 \mathrm{mbsf}$ ) was recovered at $0230 \mathrm{~h}$ on 23 January containing $5.87 \mathrm{~m}$ of surface gravel and mud from the multiple failed reentry attempts.

\section{Hole U1415N drilling operations}

Because we had the RCB coring system in place, we decided to offset the ship to immediately spud a single-bit unsupported hole. The vessel was moved 15 $\mathrm{m}$ west of Hole U1415M. We recovered the camera system, dropped a new core barrel, and started Hole $\mathrm{U} 1415 \mathrm{~N}$ at $0340 \mathrm{~h}$ on 23 January 2013. Core $1 \mathrm{R}$ was cut from 0 to 14.9 mbsf and was recovered at $1315 \mathrm{~h}$ on 23 January with $0.45 \mathrm{~m}$ of roller rocks. After retrieving Core 2R (14.9-18.9 mbsf; $0.15 \mathrm{~m}$ recovery), $4.75 \mathrm{~h}$ were spent to work the bit down to bottom before beginning to cut the next core at $2330 \mathrm{~h}$ on 23 January. Core 3R was a full $9 \mathrm{~m}$ advance (18.927.9 mbsf; $0.50 \mathrm{~m}$ recovered), and then the ROP for Core 4R (29.7-37.0 mbsf; $0.46 \mathrm{~m}$ recovered) was very high. After recovering Core $4 \mathrm{R}$, the drillers were never able to work the bit back down to bottom. The hole continued to pack off (high pump pressures) and had high/erratic torque, as seen previously during this expedition associated with the unstable/rap- idly drilled intervals. We decided to abandon Hole $\mathrm{U} 1415 \mathrm{~N}$ at $1700 \mathrm{~h}$ on 24 January. The bit cleared the seafloor at $1740 \mathrm{~h}$ and was back on the rig floor at $0145 \mathrm{~h}$ on 25 January. The core barrel that was in place during the final attempts to clean out the hole back to bottom (Core 5G) was recovered at $0125 \mathrm{~h}$ on 25 January. The four cores recovered in Hole $\mathrm{U} 1415 \mathrm{~N}$ extended from 0 to $37.0 \mathrm{mbsf}$ and recovered $1.56 \mathrm{~m} \mathrm{(4 \% )}$ of basement rock.

\section{Igneous petrology}

Coring in Holes U1415K, U1415M, and U1415N recovered mostly volcanic or hypabyssal rocks as well as a few gabbroic rocks, including orthopyroxenebearing olivine gabbro and evolved quartz-bearing lithologies such as an oxide-quartz diorite.

\section{Hole U1415K}

Sections 345-U1415K-2G-1 through 2G-4 consist of a mix of mainly fine to coarse grained sand and minor pebbles, drill cuttings, and brown mud/clay. The first interval of Section 2G-5 (Interval G5) is a mix of pebbles. The larger fragments include basalt, dolerite, and gabbro. Intervals G6-G8 contain single pieces of oxide-quartz diorite (microscopic examination reveals the presence of granophyric intergrowths of quartz and plagioclase), orthopyroxene-bearing olivine gabbro, and aphyric basalt. The distribution of principal lithologies recovered in Hole U1415K is shown in Figures F1A and F1B for all recovered lithologies, including sand (Intervals G1-G8), and for the recovered intact magmatic rocks (Intervals G6G8).

\section{Hole U1415M}

Sections 345-U1415M-2G-1 through 2G-3 consist of very fine to medium-grained sand (Intervals G1-G3). Section 2G-4 contains a coarser grain size that also includes pebbles mostly corresponding to basalt (Interval G4). Interval G5 contains several basaltic pebbles. Cut pieces correspond to aphyric basalt. The distribution of principal lithologies recovered in Hole U1415M is shown in Figure F1C.

\section{Hole U1415N}

Coring in Hole U1415N recovered olivine-bearing volcanic and hypabyssal rock. Cores 345-U1415N-1R through 4R contain basalt (mostly olivine, moderately to highly phyric) with coarser grained hypabyssal rock in the deepest core (4R; olivine-phyric basalt, dolerite, and olivine dolerite). One ghost core $(5 \mathrm{G})$ recovered fine-grained olivine dolerite and olivine-highly phyric basalt. The distribution of princi- 
pal lithologies recovered in Hole $\mathrm{U} 1415 \mathrm{~N}$ is shown in Figures F1D-F1F.

\section{Rock types}

Below, we give a brief lithologic description for each rock type recovered from the different intervals of Holes U1415K, U1415M, and U1415N based on macroscopic and, where available, microscopic observations. For one thin section from Hole U1415N, two different lithologic domains were defined. Table T2 lists the corresponding thin section, number and nature of the individual domains, characteristics of the contact between the domain, and a link to the corresponding thin section image with the domain boundaries marked.

\section{Diorite}

Two intervals of diorite were recovered from Core 345-U1415K-2G (Intervals G5 and G6). The diorite is medium grained and equigranular with a seriate to granular texture (Fig. F2). Based on thin section observations, diorite is composed of plagioclase $(60 \%)$, clinopyroxene $(25 \%-30 \%)$, orthopyroxene $(<1 \%-$ $4 \%)$, quartz $(3 \%-10 \%)$, oxide $(3 \%-5 \%)$, and trace amounts of amphibole that is assumed to be of primary origin (Fig. F3B). Plagioclase is euhedral to subhedral and tabular. Clinopyroxene and orthopyroxene are subhedral to anhedral with a subequant habit. Quartz is anhedral and irregular interstitial. In Sample 345-U1415K-2G-5, 13-15 cm (Piece 2), quartz forms granophyric texture together with plagioclase (Fig. F3A). The evolved composition of this rock is also expressed by the presence of apatite and zircon (Fig. F3B-F3D).

\section{Olivine gabbro}

Two intervals of olivine gabbroic lithologies were recovered (Sample 345-U1415K-2G-5, 18-25 cm [Piece $3]$, in Interval G7 and Sample 345-U1415N-4R-1, $48.5-57 \mathrm{~cm}$ [Piece 12], in Interval 16). Gabbro is fineto medium-grained equigranular granular rocks. The primary mineralogy is olivine $(2.5 \%-10 \%)$, plagioclase $(40 \%-60 \%)$, clinopyroxene $(35 \%-45 \%)$, orthopyroxene $(2 \%-3 \%)$, and oxide $(0.5 \%-1 \%)$. Olivine is subhedral with an equant habit. Plagioclase is subhedral to anhedral with a tabular habit. Clinopyroxene is anhedral with a subequant to poikilitic habit. Orthopyroxene is subhedral with a subequant to prismatic habit. Oxide is subhedral to anhedral with an irregular habit.

\section{Basalt}

Several basaltic lithologic intervals were recovered in Holes U1415K, U1415M, and U1415N. A series of core close-up images showing the variety of the recovered basalt rocks are presented in Figure F4. Two analyses of cored basalt in Hole U1415N (olivinephyric basalt) revealed relatively evolved compositions, compared to the gabbroic rocks drilled at Site U1415, with Mg\# (100 × cationic Mg/[Mg + Fe] with all Fe recalculated as $\mathrm{Fe}^{2+}$ ) of 63.8 and 76.1, respectively. One sample is interpreted as a former chilled margin (Fig. F4E). The intervals include aphyric basalt as well as a range of olivine-phyric basalt (sparsely to highly phyric). Olivine phenocryst contents range from $1 \%$ to $20 \%$ with minor plagioclase $(<1 \%-5 \%)$. Plagioclase phenocrysts are subhedral to anhedral, may show abundant oscillatory zoning, and range in mode from $<1$ to $10 \mathrm{vol} \%$.

A characteristic feature is the presence of Cr-spinel $(<1 \%)$ as phenocrysts and microphenocrysts in many basalt pieces (Fig. F5). Some phenocrysts and microphenocrysts show corroded rims where the Crspinel reacted to magnetite. Cr-spinel also occurs as inclusions in olivine phenocrysts. In Sample 345U1415N-1R-1, 52-54 cm (Piece 10), millimeter-sized glomerocrysts of olivine and plagioclase are visible within an intergranular matrix consisting of olivine, plagioclase, and clinopyroxene (Fig. F6A). These are regarded as xenocrysts that occasionally show subgrains (for details see "Structural geology"). Spherical inclusions of sulfide in olivine within this sample are interpreted as early immiscible sulfide droplets, indicating early sulfide saturation (Fig. F6B, F6C). Plagioclases exhibit a strong patchy zoning (Fig. F6D).

\section{Dolerite}

Several doleritic lithologic intervals were recovered in Hole U1415N. Dolerite consists of olivine $(<1 \%-$ $10 \%)$, plagioclase $(50 \%-60 \%)$, clinopyroxene $(40 \%)$, and oxide $(<1 \%)$. A thin section was cut from Sample 345-U1415N-5G-1, 8-16 cm (Piece 2; Interval G2). Olivine, now completely altered, is euhedral to subhedral with an equant habit. Larger crystals of plagioclase are euhedral to subhedral and tabular and show strong growth zonation effects (Fig. F7A, F7B). Interstitial plagioclase in this sample is lath-shaped to acicular. Interstitial clinopyroxenes are anhedral, form subophitic clusters, and show signs of fast crystal growth (Fig. F7C, F7D). Oxide is anhedral and subequant. 


\section{Metamorphic petrology}

\section{Background alteration}

\section{Hole U1415K}

Cores recovered in Hole U1415K contain several lithologies, including sand and fine gravel, as well as gabbroic, doleritic, and basaltic rubble (see METLOGS in "Supplementary material"). The sand and fine gravel are too fine grained to assess alteration but appear to have undergone extensive seafloor weathering based on the light brown sediment color. Ghost Core 345-U1415K-2G includes diverse lithologies with variable alteration: Interval G5 is highly altered diorite, Interval G6 is highly altered disseminated oxide gabbronorite, Interval G7 is moderately altered orthopyroxene-bearing olivine gabbro, and Interval G8 is slightly altered aphyric basalt. In the gabbro, olivine and clinopyroxene are completely replaced, although plagioclase remains only slightly altered. Olivine is replaced by serpentine, magnetite, tremolite, and pyrite. Clinopyroxene is highly to completely altered to green amphibole. In diorite and basalt, matrix plagioclase is only slightly altered. Many of the rocks from this core contain abundant disseminated oxide and pyrite. Relict orthopyroxene is not observed in this core, although chlorite-dominated pseudomorphic aggregates may be alteration products after orthopyroxene. Both clinopyroxene and plagioclase from Interval G7 are more altered than more primitive gabbro or troctolite from other Hess Deep holes.

Clay veins are observed in a few pieces of rubble from Hole U1415K. In Sample 345-U1415K-2G-5, $18-25 \mathrm{~cm}$ (Piece 3), a network of dark green veins with a very soft filling of clay minerals is present (see VEIN_HALO.XLSX in METLOGS in "Supplementary material"). The veins lack halos and show a sharp contact with the host rock. Vein shape is irregular, with variable thicknesses of $<1-2 \mathrm{~mm}$.

\section{Hole U1415M}

Cores recovered in Hole U1415M include fine sediment as well as fine to coarse gravel. The sediment is too fine grained to assess alteration. The gravel appears slightly altered to low-temperature alteration products (i.e., clay minerals). Interval G5 is coarse gravel comprised of aphyric basalt. Alteration in the basalt from this interval is moderate with moderate serpentinization of olivine and abundant sulfide mineralization disseminated within the groundmass and also forming fine sulfide veins.

\section{Hole U1415N}

Cores recovered in Hole U1415N are primarily olivine-phyric basalt and olivine dolerite with very fine grained matrixes, with one piece of corona-textured olivine gabbro at the base of the hole (Interval 16). The degree of alteration of the basalt and dolerite is difficult to assess in hand sample but appears to range from $10 \%$ to $30 \%$, with some intervals (i.e., Interval 8) more extensively altered as much as 90\% (see METLOGS in "Supplementary material"). The fine-grained groundmass includes plagioclase and clinopyroxene that appear fresh to slightly altered. Abundant reddish clay occurs in the groundmass as an alteration product. Clinopyroxene phenocrysts are commonly $<10 \%$ altered to amphibole. Alteration of olivine phenocrysts ranges from $60 \%$ to $100 \%$, with replacement by serpentine in mesh texture, clay minerals, chlorite, and amphibole in addition to pyrite in most of the intervals in Hole U1415N. The olivine phenocrysts are noticeably more altered along the margins of pieces and within vein halos, and in these areas the serpentine mesh is commonly replaced by serpentine + talc \pm chlorite (Fig. F8).

Background alteration in gabbro is moderate $(10 \%-$ $30 \%$ replacement of primary phases). In olivine-bearing gabbro (Interval 16), olivine is primarily replaced by talc and chlorite (Sample 345-U1415N-4R-1, $48.5-57 \mathrm{~cm}$ [Piece 12]). Chlorite rims surround relict olivine where in contact with plagioclase, forming olivine corona textures. Clinopyroxene is 50\%-90\% altered to green amphibole, secondary clinopyroxene, chlorite, clay minerals, oxides, and sulfides. Orthopyroxene was identified in Thin Section 93 (Sample $345-\mathrm{U} 1415 \mathrm{~N}-4 \mathrm{R}-1,52-54 \mathrm{~cm}$ ) and is $70 \%$ altered to talc and amphibole. Plagioclase is variably altered from $<10 \%$ to $50 \%$. Plagioclase is primarily altered to chlorite and clay minerals with lesser amounts of secondary plagioclase, zeolite, and oxide. Chlorite rims are weakly developed around olivine and orthopyroxene. Pyrite is abundant as a disseminated phase in the groundmass and is present in the alteration products after olivine.

The major type of vein is composed of clay minerals that replace former vein-filling chlorite or prehnite (see VEIN_HALO.XLSX in METLOGS in "Supplementary material"). An amphibole vein observed in Interval 2 (Sample 345-U1415N-1R-1, 11-12 cm [Piece 3]) is partially altered to chlorite. Chlorite and prehnite in veins are commonly replaced by clay minerals. Prehnite in veins often shows radiating texture, whereas chlorite veins typically have cross- 
fiber texture. These original textures are preserved in spite of partial replacement by clays (Fig. F9).

\section{Metamorphic conditions and degrees of alteration}

The dominant alteration of the rock recovered in Holes U1415K, U1415M, and U1415N ranged from greenschist facies to subgreenschist facies conditions. Alteration in the basaltic and doleritic rocks is more intense along the edges of these pieces, suggesting that hydration occurred primarily along fractures. These samples lack compelling evidence for higher temperature alteration. Alteration in the gabbro at the base of Hole U1415N shows corona textures between olivine and plagioclase comparable to many samples in Hole U1415J, indicating partial hydration in the lower amphibolite facies.

\section{Structural geology}

Core from Holes U1415K-U1415N comprises a collection of aphyric basalt; olivine basalt; dolerite, diorite, and gabbro clasts; and sand. All pieces were relatively small $(5 \mathrm{~cm}$ maximum length), not cored or oriented, and from loose rubble.

\section{Magmatic structures}

\section{Hole U1415K}

Ghost core recovered in Hole U1415K consists of four sections of clay and sand with some cuttings and gravel in the lowermost part of Section 345U1415K-2G-4. Section 2G-5 contains an interval of gravel followed by three cobbles: oxide-quartz diorite, olivine gabbro, and aphyric basalt. None of the pieces show macroscopic magmatic foliation. Microscopic examination of diorite collected from the gravel (Sample 345-U1415K-2G-5, 10-12 cm [Piece 1]) shows rare undulose extinction in plagioclase crystals and a lack of a magmatic foliation. Similarly, microscopic examination of oxide-quartz diorite (Sample 2G-5, 13-15 cm [Piece 2]) confirms the lack of magmatic foliation; however, the sample shows aligned Fe-Ti oxides and rare undulose extinction in plagioclase.

\section{Hole U1415M}

Ghost core recovered in Hole U1415M (Core 345U1415M-2G) consists of four sections of sand with some cuttings and an aphyric basalt gravel in the lowermost part of Section 2G-4. No magmatic flow features were observed.

\section{Hole U1415N}

Coring in Hole U1415N recovered five cores consisting of basalt and dolerite. The basalts are mostly olivine phyric, with no macroscopic magmatic flow structures observed. Microscopically, a sparsely plagioclase phyric aphanitic basalt (Sample 345U1415N-4R-1, 12-15 cm [Piece 3]) contains plagioclase microlites that define a moderate magmatic flow fabric parallel to the chilled margin of the sample (Fig. F10A, F10B). Microscopic observations indicate that most phaneritic basaltic clasts show a local and weak alignment of matrix plagioclase crystals.

Olivine xenocrysts in phaneritic olivine phyric basalt frequently occur as glomerocrysts, which can include plagioclase crystals (e.g., Sample 1R-1, 52-54 $\mathrm{cm}$ [Piece 10]). The xenocrysts also occasionally host subgrains (Fig. F10C), indicating that they have undergone limited crystal-plastic deformation. Perhaps the xenocrysts were inherited from crystal mush forming in a crustal magma chamber. In rare cases, plagioclase crystals in the matrix of the basalts may show deformation twinning and undulose extinction (Fig. F10D).

Macroscopically, phaneritic dolerites do not exhibit magmatic foliation. In thin section, however, a subophitic dolerite (Sample 4R-1, 52-54 cm [Piece 12]) shows weak magmatic foliation flowing around an anorthositic troctolite xenolith/enclave (Fig. F11A). This piece is similar to several pieces recovered in Sections 345-U1415N-4R-1 and 5G-1 and is therefore presumed to also have weak magmatic foliation. Plagioclase crystals within dolerite show sparse undulose extinction, bending, and deformation twinning (Fig. F11B). The smallest plagioclase crystals within the anorthositic troctolite xenolith also exhibit crystal-plastic deformation in the form of subgrains, deformation twinning, and undulose extinction (Fig. F11C).

\section{Crystal-plastic deformation}

No structurally continuous subsolidus crystal-plastic deformation was observed in the recovered sections.

\section{Cataclastic deformation}

Macroscopically, pieces recovered from cores in Holes U1415K and U1415N show limited brittle deformation restricted to several pieces hosting open 
fractures. These open fractures are low density $(<1$ or $1-5$ fractures per $10 \mathrm{~cm}$ ) and have no apparent offset.

\section{Alteration veins}

Alteration veins are present in the majority of pieces recovered in Holes U1415K and U1415N and represent a ubiquitous, although volumetrically insignificant, component of the recovered rock types. Veins are generally rare (less than a few veins per $10 \mathrm{~cm}$ of recovery), with only one piece characterized by a high density of tiny veins forming an anastomosing network. The alteration veins are all very thin $(<0.1$ $\mathrm{cm}$ maximum thickness, in most cases $<0.05 \mathrm{~cm}$ ) and together represent $<1 \%$ of the core volume.

Aphyric and olivine phyric basaltic rock, gabbro, and dolerite in both Holes U1415K and U1415N host veins filled with various secondary minerals, including chlorite, clays, and prehnite. Prehnite veins typically cut chlorite veins. In a few examples, chlorite and prehnite are found in the same vein, with prehnite reopening the chlorite vein and forming zoned veins with prehnite in the middle and chlorite on the walls. Basaltic clasts in Hole U1415N rarely show pale green halos variably developed around chlorite veins. Most veins are clear-cut; form networks of relatively planar, parallel, and/or curved sets; and crosscut each other, showing no preferred orientation at the piece scale. Because all pieces are unoriented, no orientation data were collected.

\section{Inorganic geochemistry}

Chemical analyses were performed on two basaltic samples from Hole U1415N. Samples were selected by representatives from all expertise groups within the shipboard scientific party. Sample 345-U1415N$2 \mathrm{R}-1,3-5 \mathrm{~cm}$, is moderately olivine phyric and Sample $4 \mathrm{R}-1,12-15 \mathrm{~cm}$, is sparsely olivine and plagioclase phyric. Geochemical samples were cut within areas visibly depleted in phenocrysts; in contrast, the associated thin sections were selected in zones where the minerals could easily be optically characterized. Major and trace elements were determined by inductively coupled plasma-atomic emission spectroscopy, and gas chromatography was used for $\mathrm{S}, \mathrm{H}_{2} \mathrm{O}$, and $\mathrm{CO}_{2}$ quantifications. Results are reported in Table T1 in the "Geochemistry summary" chapter (Gillis et al., 2014c). Major and trace elements are reported on a volatile-free basis.

Hole U1415N basalt has high loss on ignition (LOI; 1.9-2.6 wt\%) and $\mathrm{H}_{2} \mathrm{O}$ content (2.1-2.7 wt\%), indicating their advanced degree of alteration $(\sim 17 \%-$ $40 \%$; see "Metamorphic petrology" and thin sec- tion descriptions in "Core descriptions"). Nevertheless, this basalt plots in a narrow range of $\mathrm{SiO}_{2}(47.7-$ $49.3 \mathrm{wt} \%)$ and has low $\mathrm{TiO}_{2}(0.9-1.2 \mathrm{wt} \%), \mathrm{Na}_{2} \mathrm{O}$ (2.1-2.9 wt\%), and $\mathrm{K}_{2} \mathrm{O}(<0.04 \mathrm{wt} \%)$ contents (Figs. F12, F13), as is expected from tholeiitic mid-oceanridge basalt. This suggests that the basalt's alkali content was not strongly affected by interaction with seawater-derived fluids.

In contrast to their relatively narrow range of $\mathrm{SiO}_{2}$ contents, Hole U1415N basalts have relatively variable compositions for most other major elements. Sample 345-U1415N-2R-1, 3-5 cm, is characterized by high $\mathrm{MgO}$ (14.7 wt\%), Ni (530 ppm), and $\mathrm{Cr}$ (1140 ppm) contents (Fig. F13; see also Table T1 in the "Geochemistry summary" chapter [Gillis et al., 2014c]). The high $\mathrm{MgO}$ and Ni concentrations reflect the primary modal olivine content, and the high $\mathrm{Cr}$ content reflects the occurrence of Cr-spinel in the analyzed sample (see "Igneous petrology" and thin section descriptions in "Core descriptions"). These data most likely reflect the accumulation of olivine and chromite rather than representing an exotic picrobasaltic liquid composition. Sample 345-U1415N$4 \mathrm{R}-1,12-15 \mathrm{~cm}$, is characterized by relatively high $\mathrm{Al}_{2} \mathrm{O}_{3}$ (17.9 wt $\left.\%\right)$ and $\mathrm{CaO}(11.8 \mathrm{wt} \%)$ contents, which may reflect the presence of plagioclase phenocrysts in the sample (see "Igneous petrology" and thin section descriptions in "Core descriptions").

Both samples have low incompatible trace element contents (e.g., $\mathrm{Y}=\sim 21-27 \mathrm{ppm}, \mathrm{Zr}=\sim 39-55 \mathrm{ppm}$ ), similar to basalt recovered in Hole U1415J and typical of primitive mid-ocean-ridge basalt compositions (Figs. F12, F13). Site U1415 basalts overlap in composition with basalts recovered at Ocean Drilling Program Site 894 (Scientific Party, 1993; Allan et al., 1996) and plot at the most depleted and primitive end of the field of Eastern Pacific Rise basaltic compositions (Fig. F13).

\section{Physical properties}

Magnetic susceptibility and color reflectance physical property measurements were only collected for cores recovered in Hole U1415N. These data were acquired using the Section Half Multisensor Logger with a measurement interval of $1 \mathrm{~cm}$. Raw data were uploaded to the Laboratory Information Management System database and subsequently filtered to remove spurious points that correspond to empty intervals in the liner, broken pieces, and pieces that were too small. Raw and filtered data are available in PHYSPROP in "Supplementary material." Magnetic susceptibility ranges from $\sim 170 \times 10^{-5}$ to $3100 \times 10^{-5}$ SI. Color reflectance parameters $\mathrm{L}^{*}, \mathrm{a}^{*}$, and $\mathrm{b}^{*}$ mean 
values are $33.6 \pm 5.6,0.2 \pm 0.5$, and $-4.0 \pm 1.3$, respectively.

\section{References}

Allan, J.F., Falloon, T., Pedersen, R.B., Shankar Lakkapragada, B., Natland, J.H., and Malpas, J., 1996. Petrology of selected Leg 147 basaltic lavas and dikes. In Mével, C., Gillis, K.M., Allan, J.F., and Meyer, P.S. (Eds.), Proc. ODP, Sci. Results, 147: College Station, TX (Ocean Drilling Program), 173-186. doi:10.2973/ odp.proc.sr.147.010.1996

Gillis, K.M., Snow, J.E., Klaus, A., Guerin, G., Abe, N., Akizawa, N., Ceuleneer, G., Cheadle, M.J., Adrião, Á., Faak, K., Falloon, T.J., Friedman, S.A., Godard, M.M., Harigane, Y., Horst, A.J., Hoshide, T., Ildefonse, B., Jean, M.M., John, B.E., Koepke, J.H., Machi, S., Maeda, J., Marks, N.E., McCaig, A.M., Meyer, R., Morris, A., Nozaka, T., Python, M., Saha, A., and Wintsch, R.P., 2014a. Bench site survey. In Gillis, K.M., Snow, J.E., Klaus, A., and the Expedition 345 Scientists, Proc. IODP, 345: College Station, TX (Integrated Ocean Drilling Program). doi:10.2204/iodp.proc.345.103.2014

Gillis, K.M., Snow, J.E., Klaus, A., Guerin, G., Abe, N., Akizawa, N., Ceuleneer, G., Cheadle, M.J., Adrião, Á., Faak, K., Falloon, T.J., Friedman, S.A., Godard, M.M., Harigane, Y., Horst, A.J., Hoshide, T., Ildefonse, B., Jean, M.M., John, B.E., Koepke, J.H., Machi, S., Maeda, J., Marks, N.E., McCaig, A.M., Meyer, R., Morris, A.,
Nozaka, T., Python, M., Saha, A., and Wintsch, R.P., 2014b. Expedition 345 summary. In Gillis, K.M., Snow, J.E., Klaus, A., and the Expedition 345 Scientists, Proc. IODP, 345: College Station, TX (Integrated Ocean Drilling Program). doi:10.2204/iodp.proc.345.101.2014

Gillis, K.M., Snow, J.E., Klaus, A., Guerin, G., Abe, N., Akizawa, N., Ceuleneer, G., Cheadle, M.J., Adrião, Á., Faak, K., Falloon, T.J., Friedman, S.A., Godard, M.M., Harigane, Y., Horst, A.J., Hoshide, T., Ildefonse, B., Jean, M.M., John, B.E., Koepke, J.H., Machi, S., Maeda, J., Marks, N.E., McCaig, A.M., Meyer, R., Morris, A., Nozaka, T., Python, M., Saha, A., and Wintsch, R.P., 2014c. Geochemistry summary. In Gillis, K.M., Snow, J.E., Klaus, A., and the Expedition 345 Scientists, Proc. IODP, 345: College Station, TX (Integrated Ocean Drilling Program). doi:10.2204/iodp.proc.345.114.2014

Le Bas, M.J., Le Maitre, R.W., Streckeisen, A., Zanettin, B., and the IUGS Subcommission on the Systematics of Igneous Rocks, 1986. A chemical classification of volcanic rocks based on the total alkali-silica diagram. J. Petrol., 27(3):745-750. http://

petrology.oxfordjournals.org/content/27/3/ 745.abstract

Shipboard Scientific Party, 1993. Site 894. In Gillis, K., Mével, C, Allan, J., et al., Proc. ODP, Init. Repts., 147: College Station, TX (Ocean Drilling Program), 45-108. doi:10.2973/odp.proc.ir.147.103.1993

Publication: 12 February 2014 MS 345-111 
Figure F1. Lithologic compositions in (A, B) Hole U1415K, (C) Hole U1415M, and (D-F) Hole U1415N. Ol = olivine.

Hole U1415K

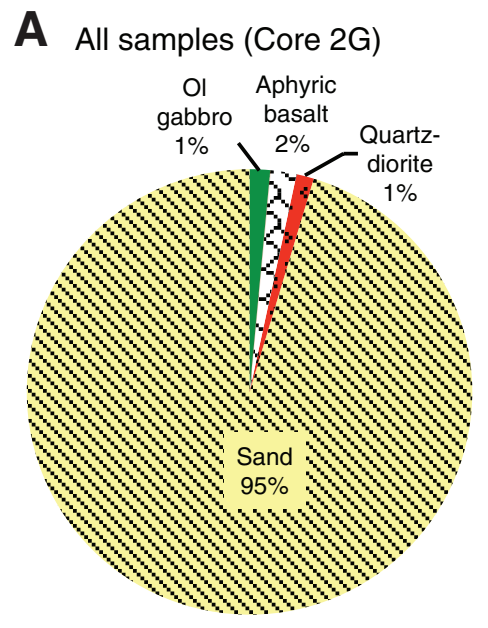

B Intervals (Core 2G, 12-34 cm)

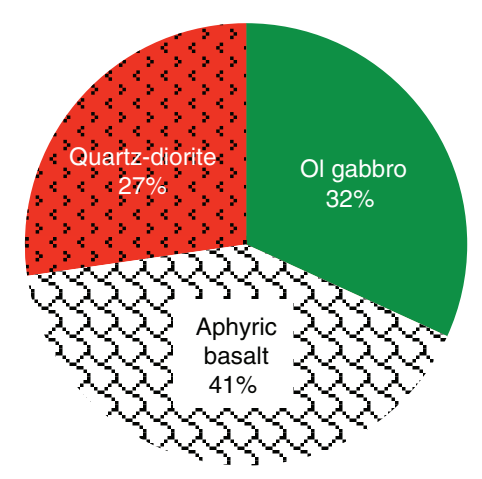

Hole U1415M

C All samples (Core 2G)

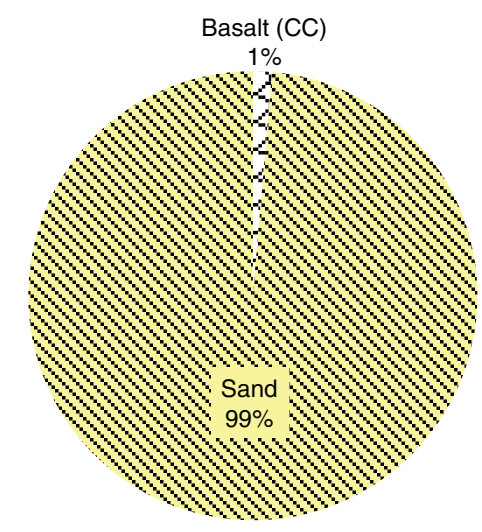

Hole U1415N

D All samples (Cores $1 \mathrm{R}$ to $5 \mathrm{G}$ )

E Cores $1 \mathrm{R}$ to $4 \mathrm{R}$

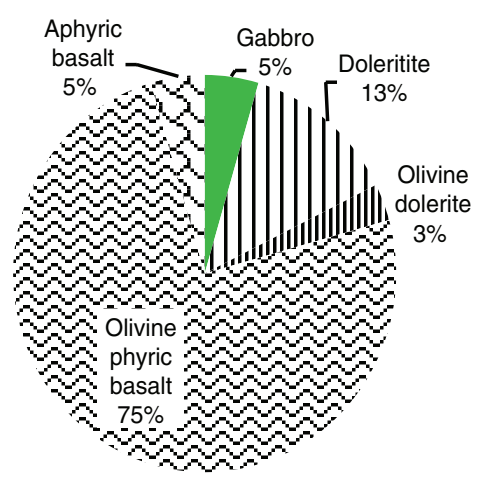

F Core 5G

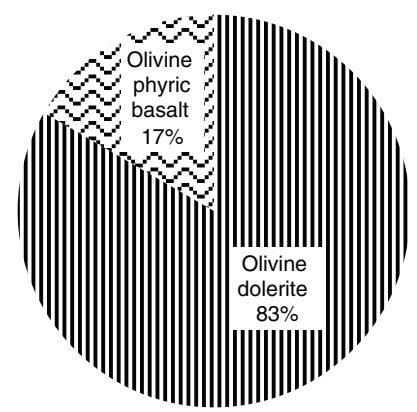


Figure F2. Oxide-quartz diorite (Thin Section 88; Sample 345-U1415K-2G-5, 14-18 cm [Piece 2]; Interval G77). Although not yet confirmed, clinopyroxene, orthopyroxene, and amphibole may be present as primary magmatic phases. The presence of interstitial quartz, iron oxide, and apatite suggests that the oxide-quartz diorite derived from a $\mathrm{SiO}_{2}$-rich melt. For details see Figure F3. A. Core close-up. B. Medium-grained oxide-quartz diorite with seriate and granular texture, consisting of plagioclase (gray crystals), quartz (white spots), oxides, and almost completely altered mafic minerals (dusty brownish/black masses; also includes oxides). Plane-polarized light. C. Under crossed polars.
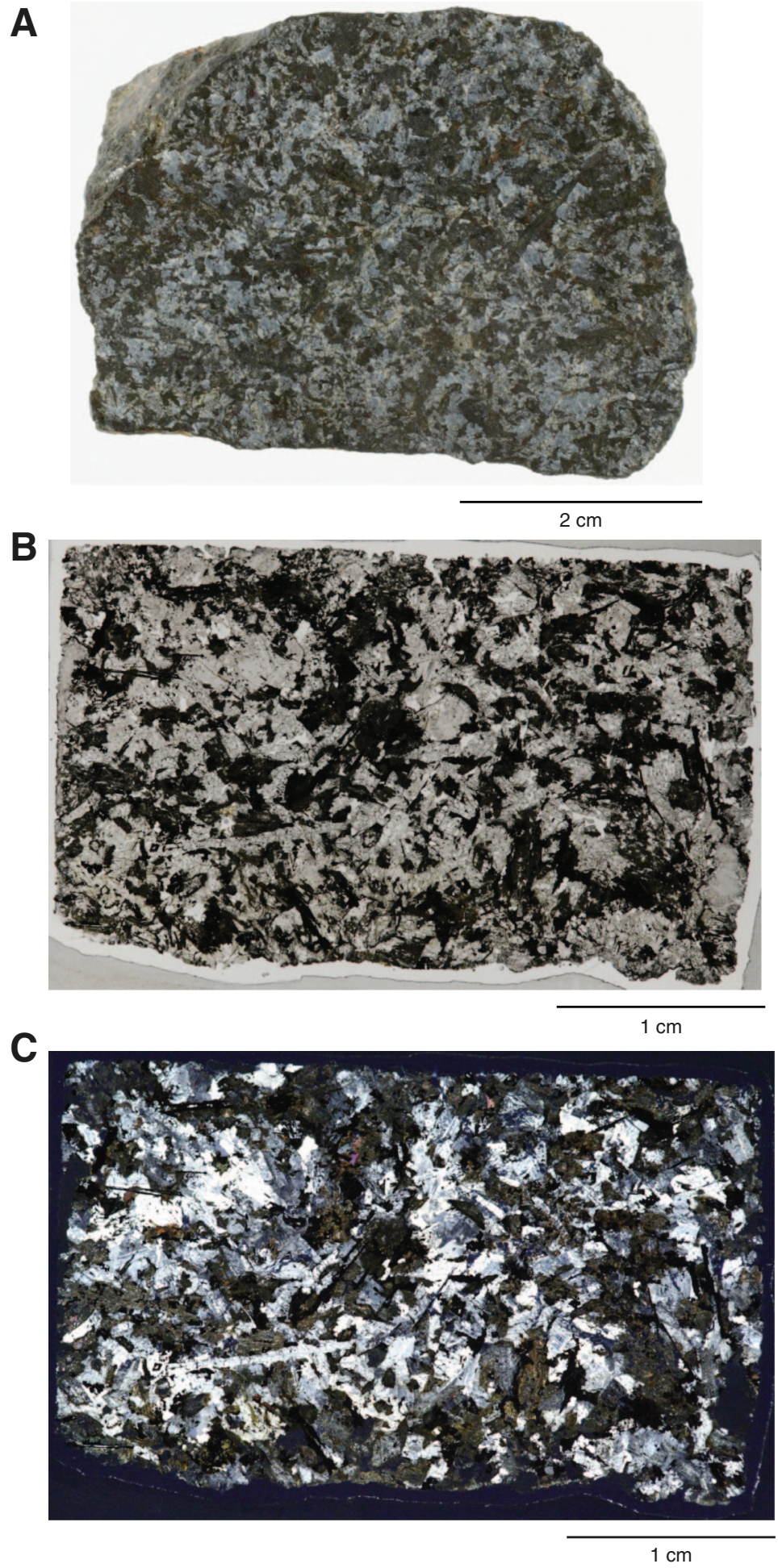
Figure F3. Oxide-quartz diorite (Thin Section 88; Sample 345-U1415K-2G-5, 13-15 cm [Piece 2]). A. Interstices are filled with quartz and a granophyric intergrowth of quartz and sodic plagioclase (Pl). B. Zircon (Zir) crystallized at the rim of brownish amphibole (Amp), interpreted as primary magmatic. C, D. Dendritic apatite (Apa) in granophyric intergrowth. A and C are under crossed polars; B and D are in plane-polarized light.

A

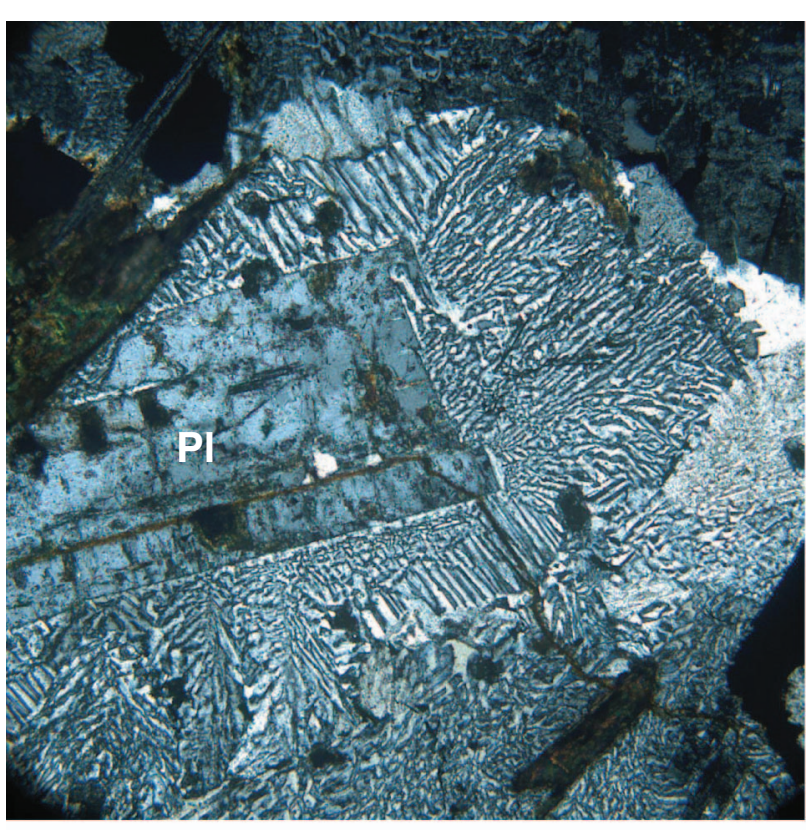

$0.5 \mathrm{~cm}$

C

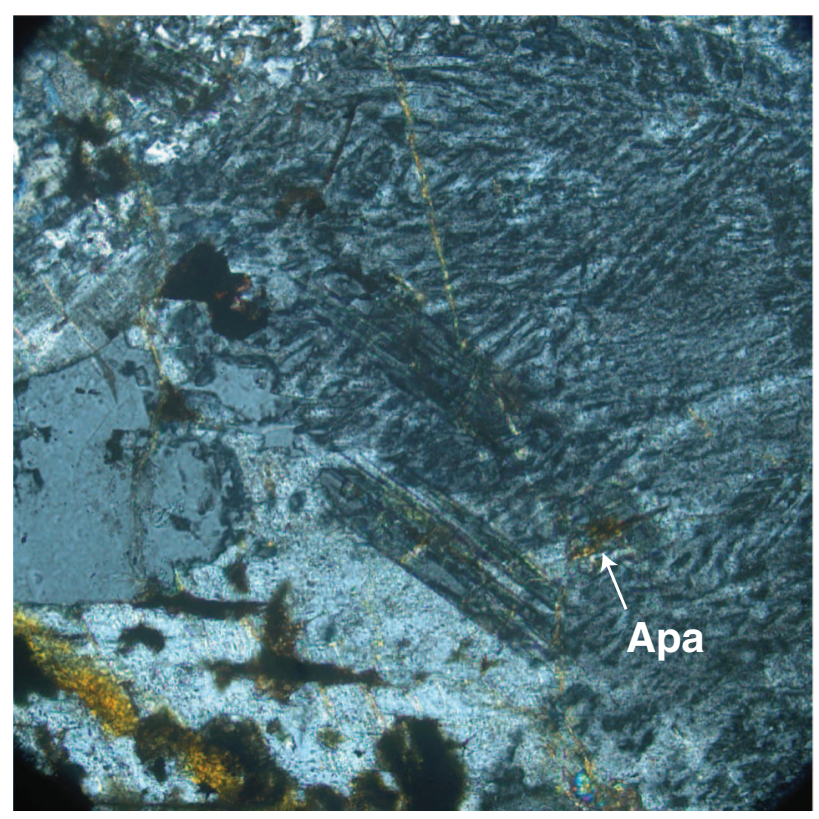

B

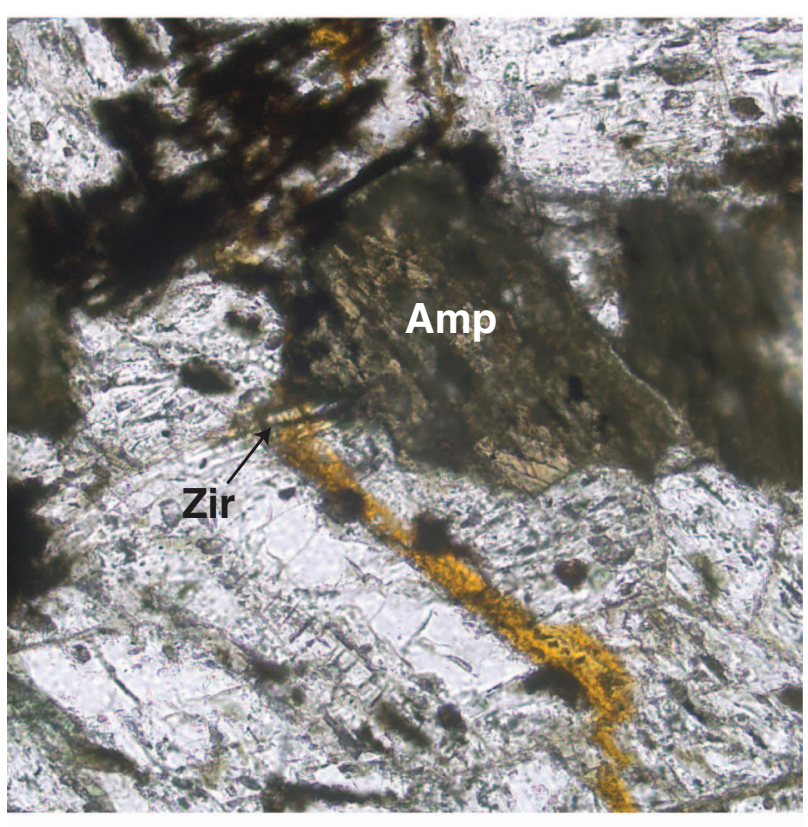

$0.1 \mathrm{~cm}$

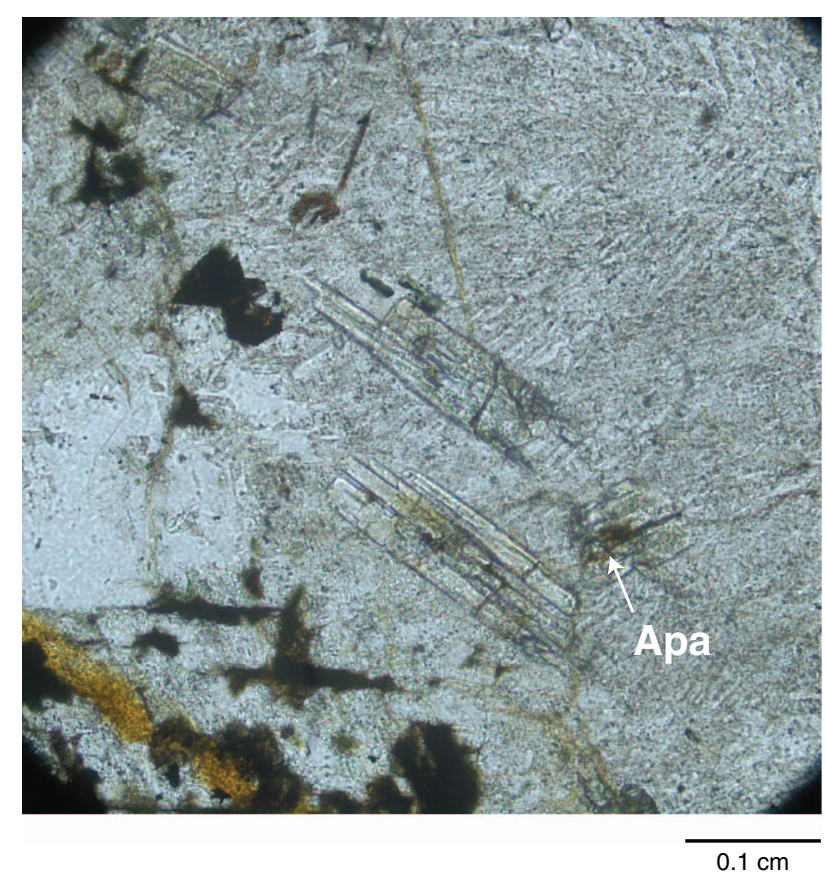


Figure F4. Range of basalt lithologies recovered in Holes U1415K and U1415N. A-C. Highly olivine-phyric basalt. (A) Sample 345-U1415N-1R-1, 52-55 cm (Piece 10). (B) Sample 345-U1415N-1R-1, 62-66 cm (Piece 12). (C) Sample 345-U1415N-2R-1, 1-8 cm (Piece 1). D. Sparsely olivine-phyric basalt (Sample 345-U1415N-4R-1, 6-11 cm [Piece 3]). E. Pillow lava fragment (Sample 345-U1415K-2G-5, 28-31 cm [Piece 4]).

A

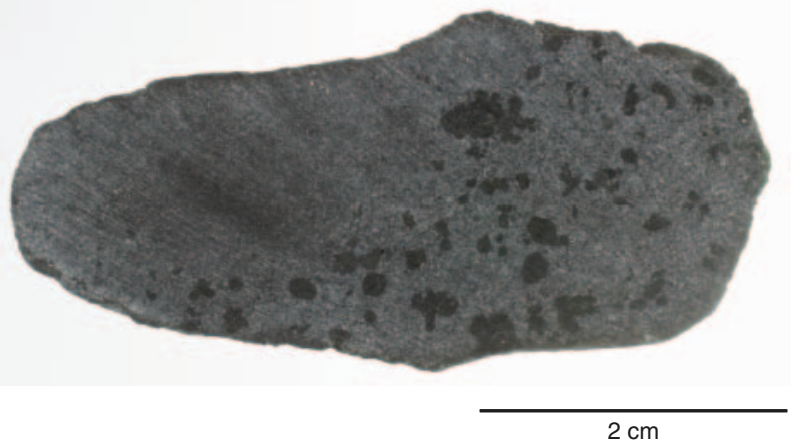

C

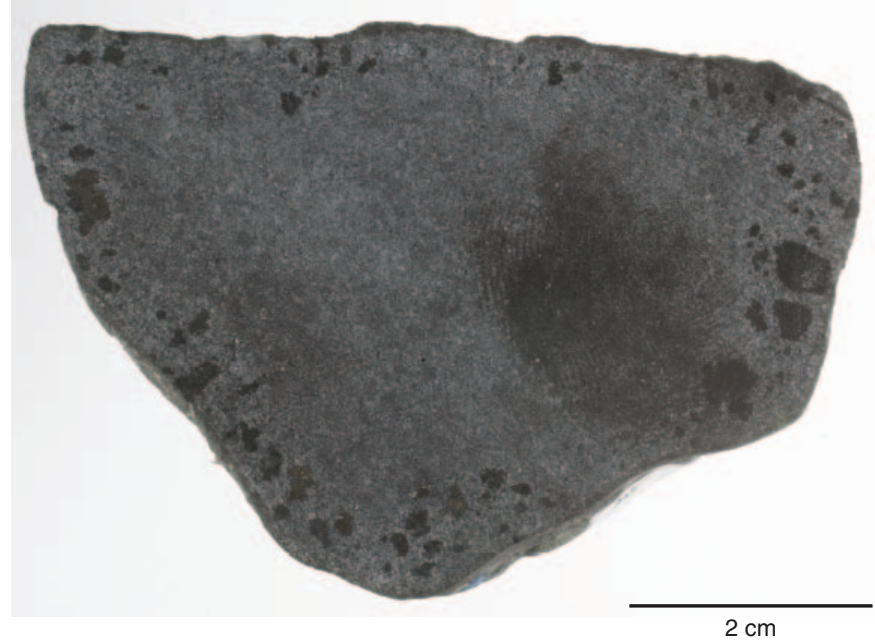

E

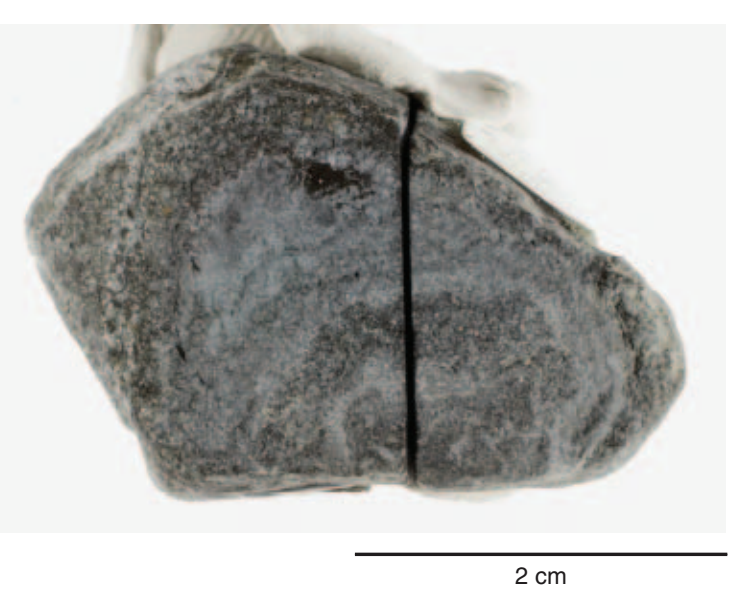

B

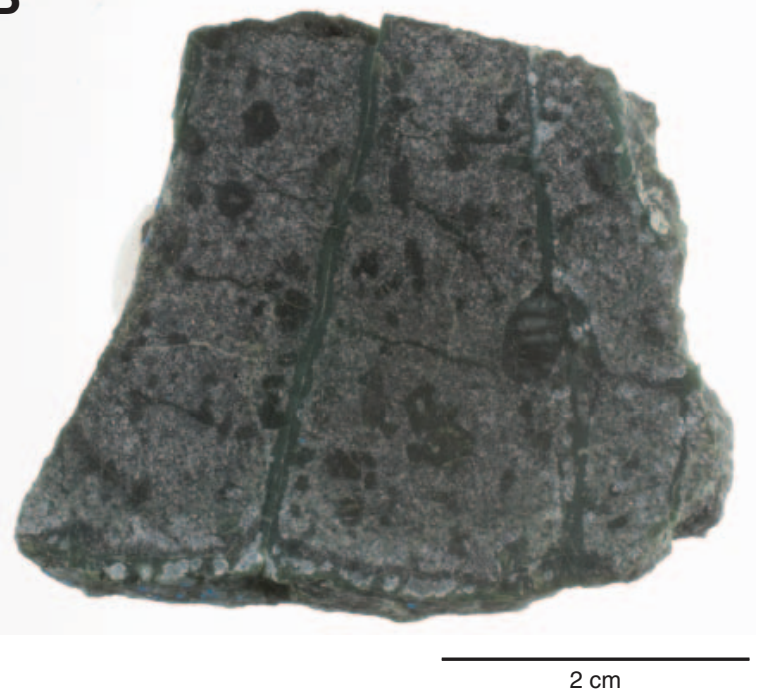

D

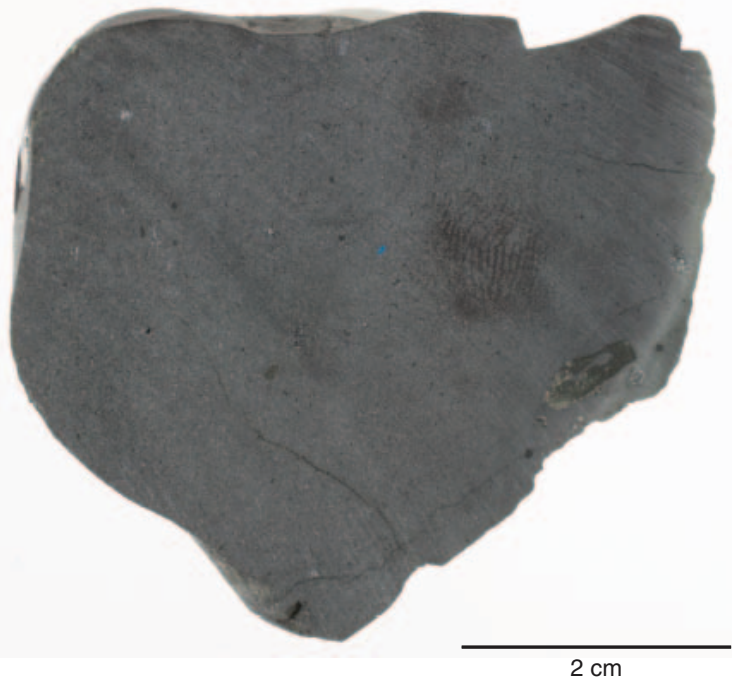


Figure F5. Olivine (Ol)-phyric basalt. A-C. Thin Section 91; Sample 345-U1415N-2R-1, 5-7 cm (Piece 1). (A, B) Brown Cr-spinel (Cr-spl) with black aureole of $\mathrm{Fe}^{3+}$-rich spinel in a matrix of olivine-phyric basalt. (C) Representative texture of the matrix of olivine-phyric basalt. $\mathrm{Cpx}=$ clinopyroxene, $\mathrm{OX}=$ oxide. D. Oscillatory zoned plagioclase (Pl) phenocrysts in olivine-phyric basalt (Thin Section 89; Sample 345-U1415N-1R-1, $52-54 \mathrm{~cm}$ [Piece 10]). The boundary between the core and rim of plagioclase is resorbed. Note that oscillatory zoning is cut by the boundary. A, C, and D are under crossed polars; B is in reflected light.

\section{A}

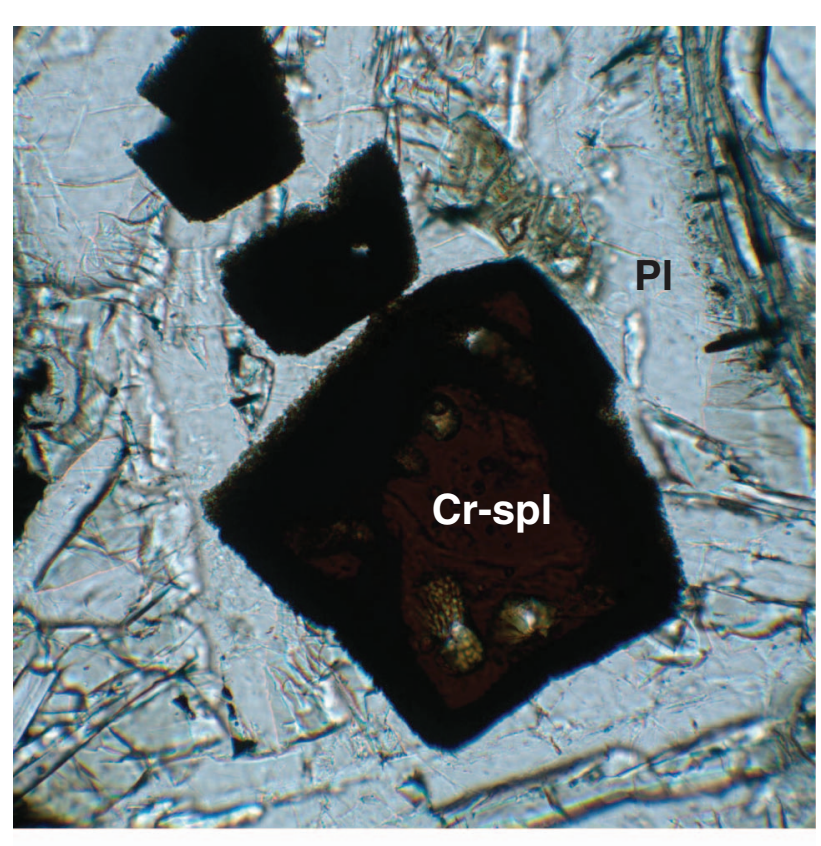

$0.25 \mathrm{~mm}$

C

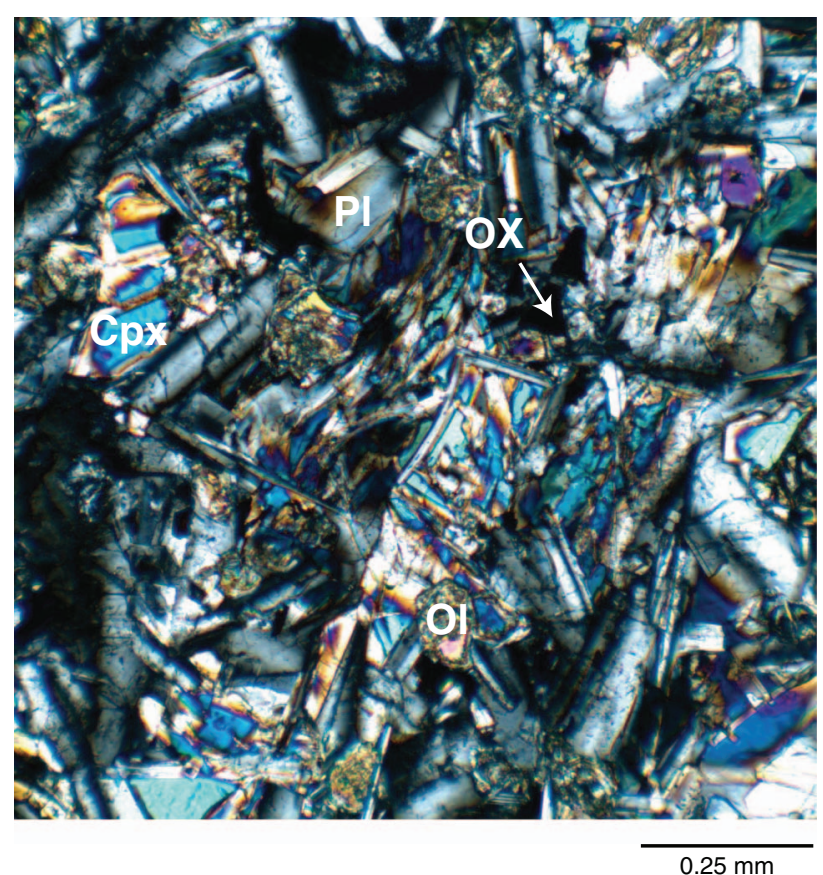

B

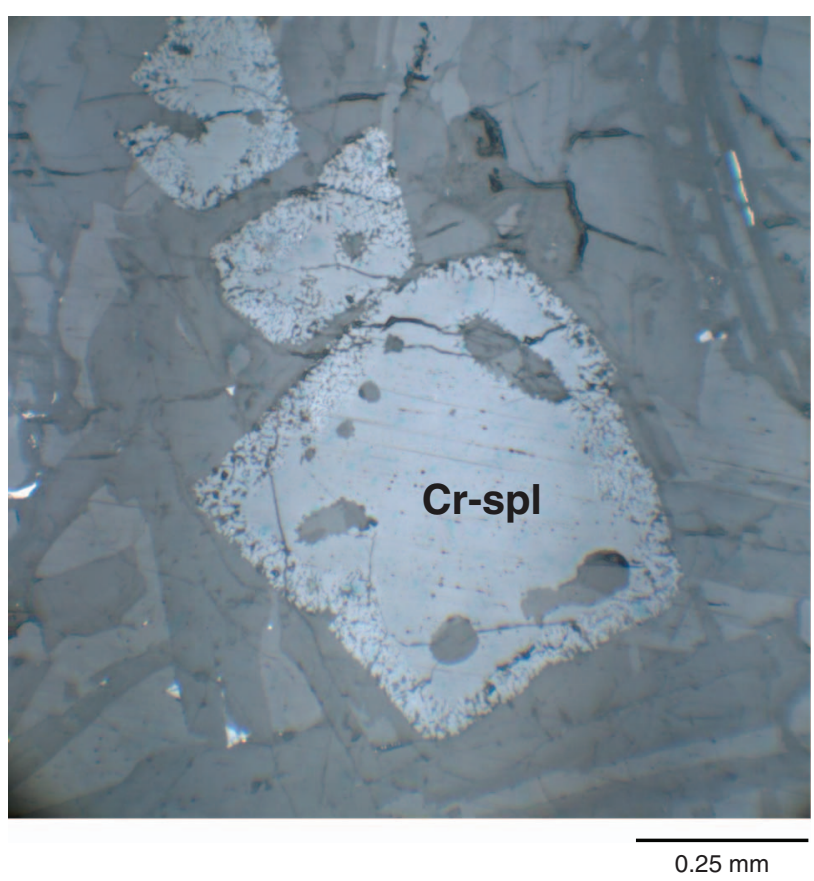

D

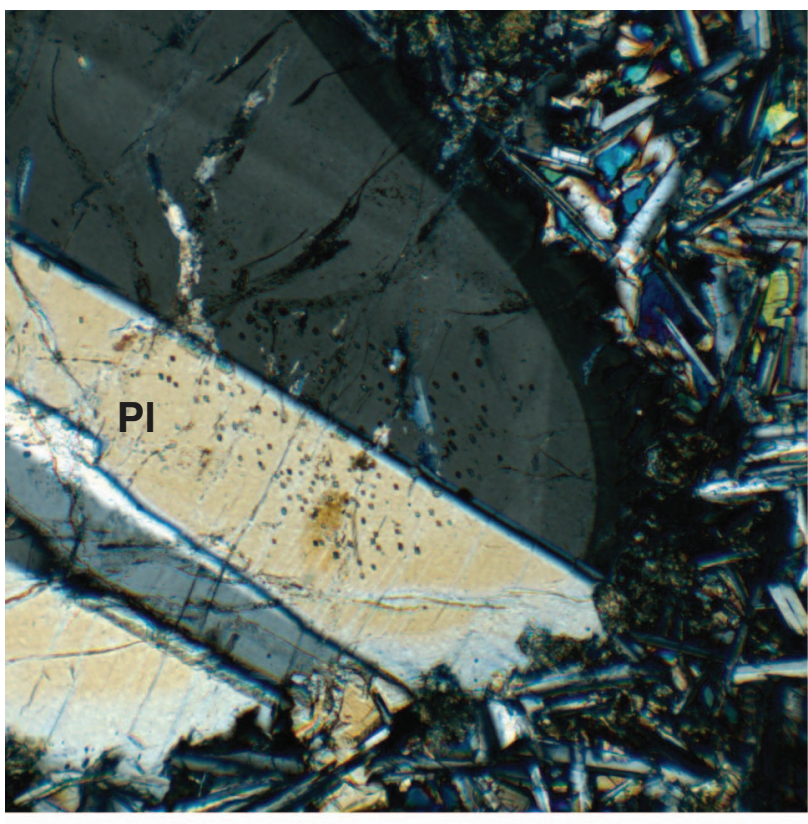

$0.25 \mathrm{~mm}$ 
Figure F6. Moderately olivine-phyric basalt (Thin Section 89; Sample 345-U1415K-1R-1, 52-54 cm [Piece 10]). A. Glomerocrysts of olivine $(\mathrm{Ol})$ and plagioclase $(\mathrm{Pl})$ in an intergranular matrix consisting of olivine, plagioclase, and clinopyroxene (Cpx). B. Globular sulfide (Sul) within olivine. The position is shown in A. C. Spinel (Spl) with fresh and altered olivine phenocrysts. $(\mathrm{Ol})=$ altered olivine. D. Complex zoning of plagioclase. A and $\mathrm{D}$ are under crossed polars; $\mathrm{B}$ is in reflected light; $\mathrm{C}$ is under plane-polarized light.

A

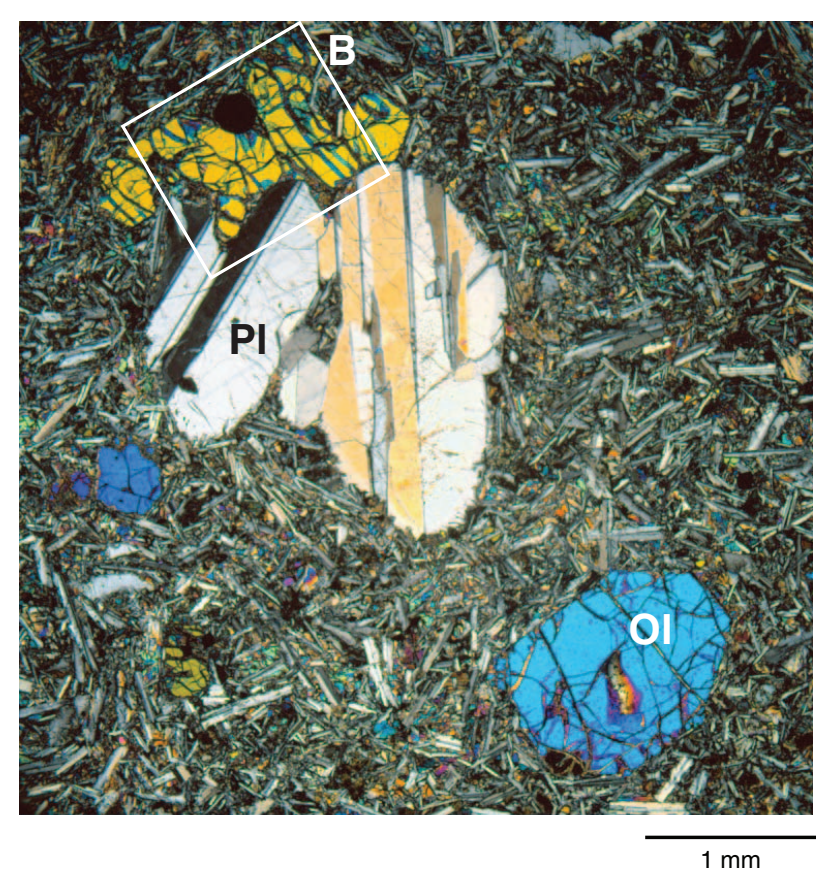

C

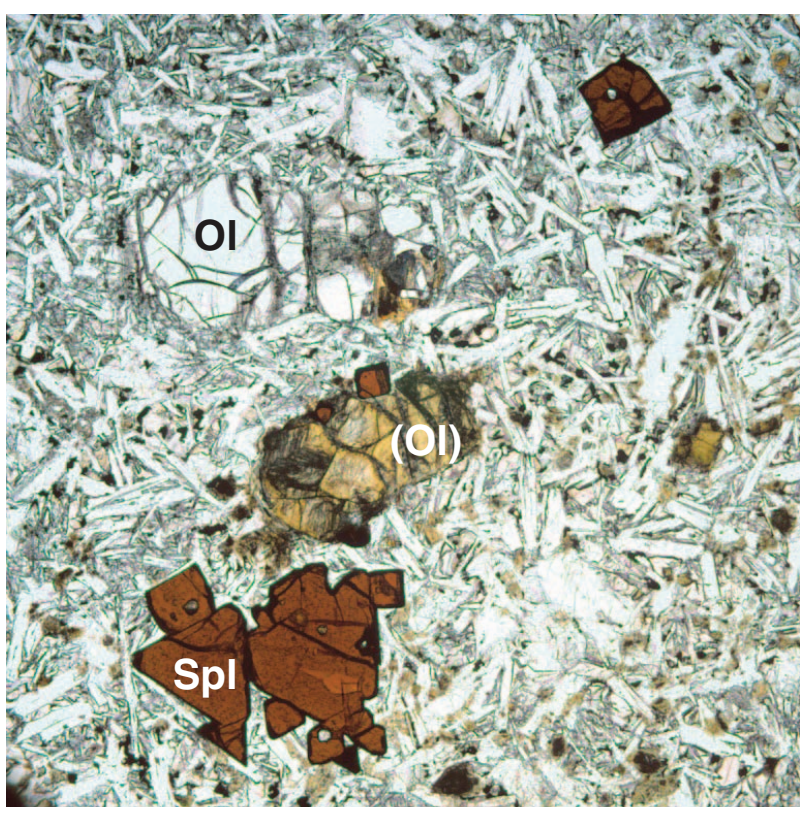

B

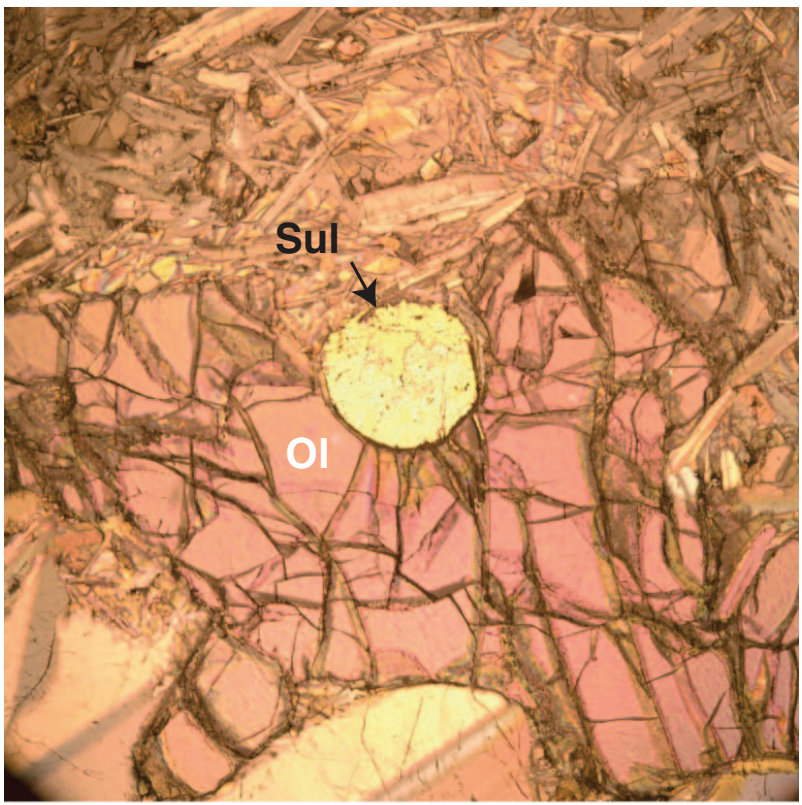

$0.5 \mathrm{~mm}$

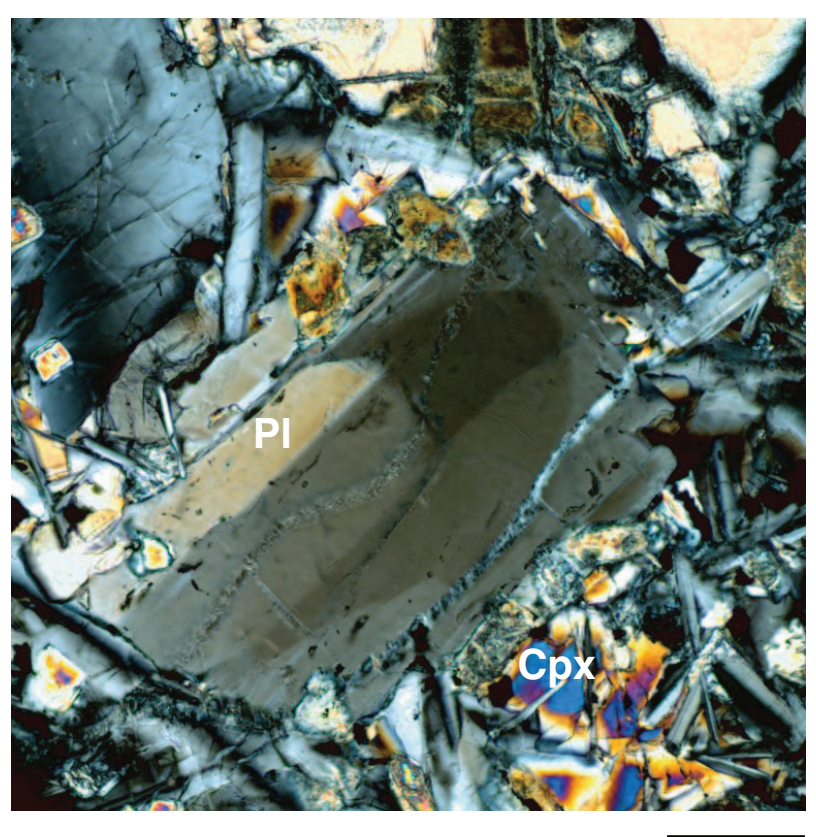

$1 \mathrm{~mm}$

$0.1 \mathrm{~mm}$ 
Figure F7. Olivine (Ol) dolerite (Thin Section 94; Sample 345-U1415N-1R-1, 13-16 cm [Piece 2]; under crossed polars). A, B. Strong growth zonation in plagioclase (Pl). C, D. Fast crystal growth of interstitial clinopyroxene $(\mathrm{Cpx}) /$ plagioclase aggregates.

A

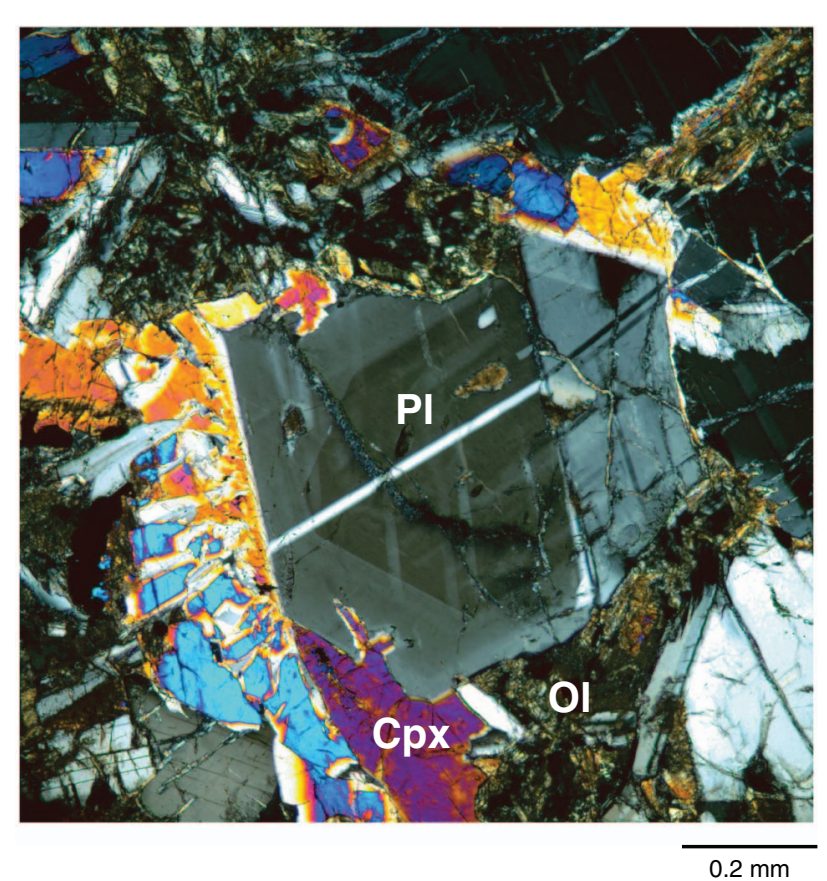

C

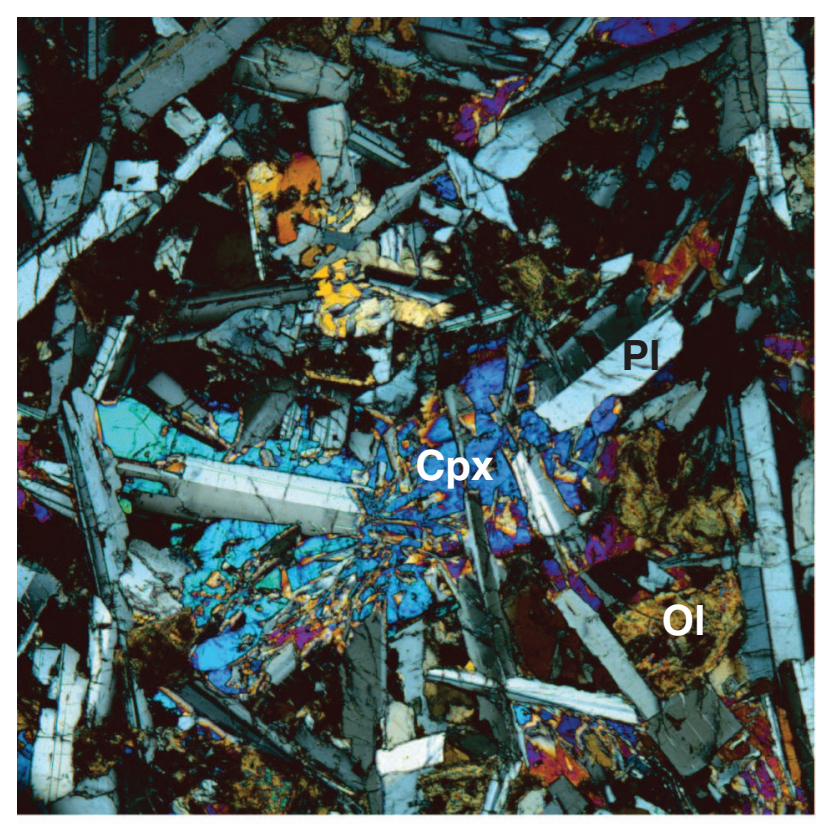

$1 \mathrm{~mm}$
B

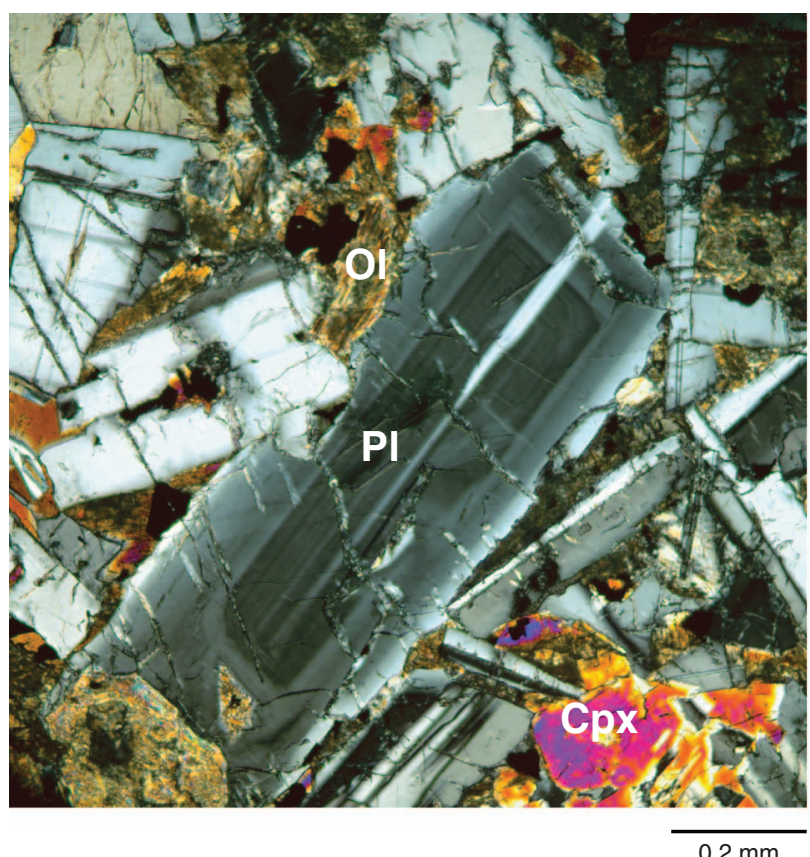

D

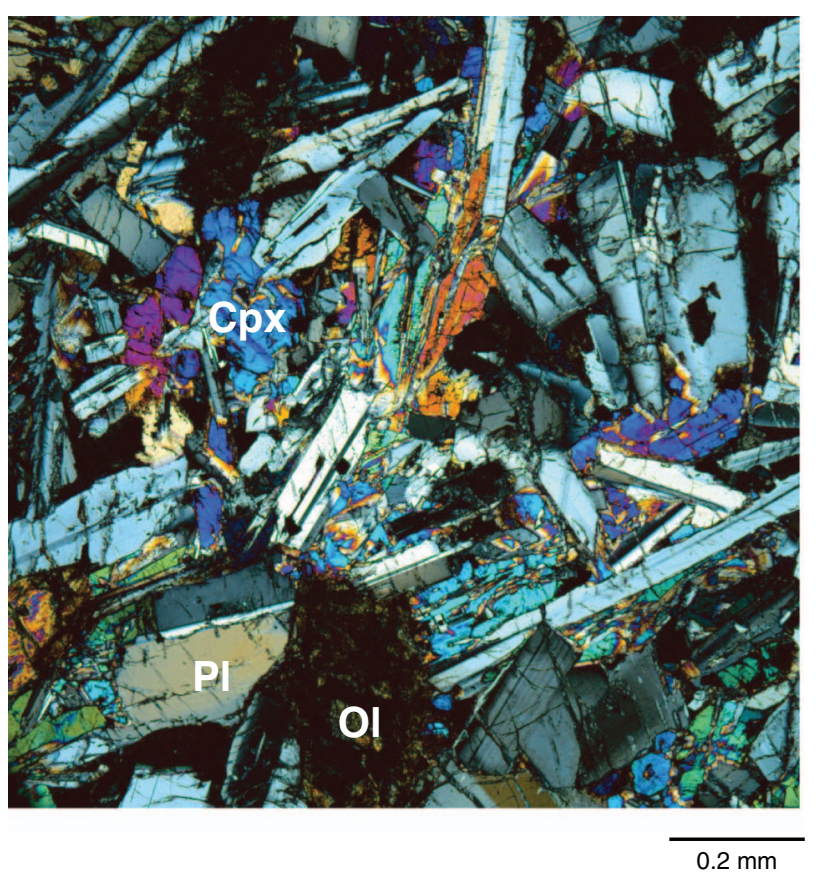


Figure F8. Alteration of olivine (Ol) phenocrysts in olivine-phyric basalt (Thin Section 92; Sample 345U1415N-2R-1, 5-7 cm [Piece 1]). Olivine near the edge of the sample is highly altered to serpentine (Srp), clay, and pyrite (Py). In contrast, phenocrysts in the center of the sample are fresh with only minor serpentinization. A. Plane-polarized light. B. Under crossed polars.
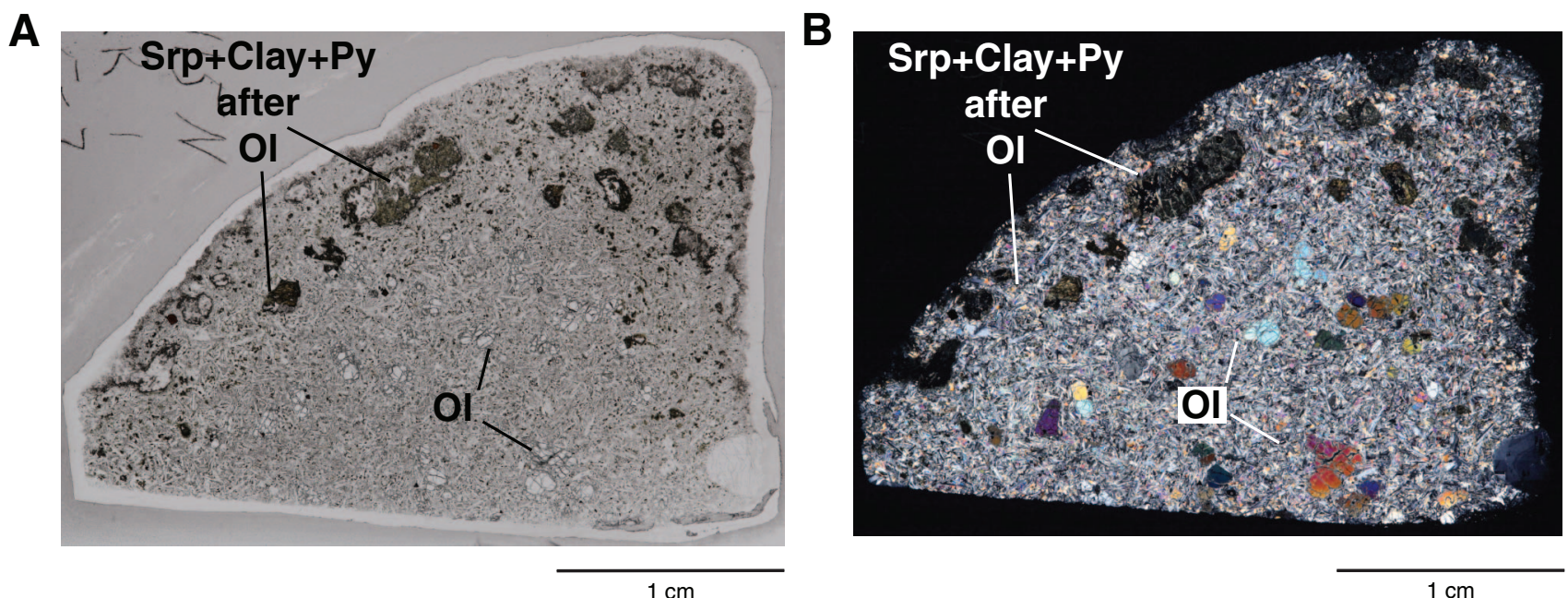
Figure F9. Clay alteration overprinting (Thin Section 92; Sample 345-U1415N-4R-1, 12-13 cm [Piece 3]; under crossed polars). A. Chlorite (Chl) and prehnite (Pr) veins (v.) showing overprinting by clay (Cl) alteration with preservation of cross-fiber texture in olivine-sparsely phyric basalt. Box shows location of B. B. Chlorite vein with clay replacement and by an unfilled crack. Plagioclase (Pl) shows slight offset, suggesting that the crack acted as a transfer fracture; chlorite was injected in two parallel cracks that end on the fracture.

A

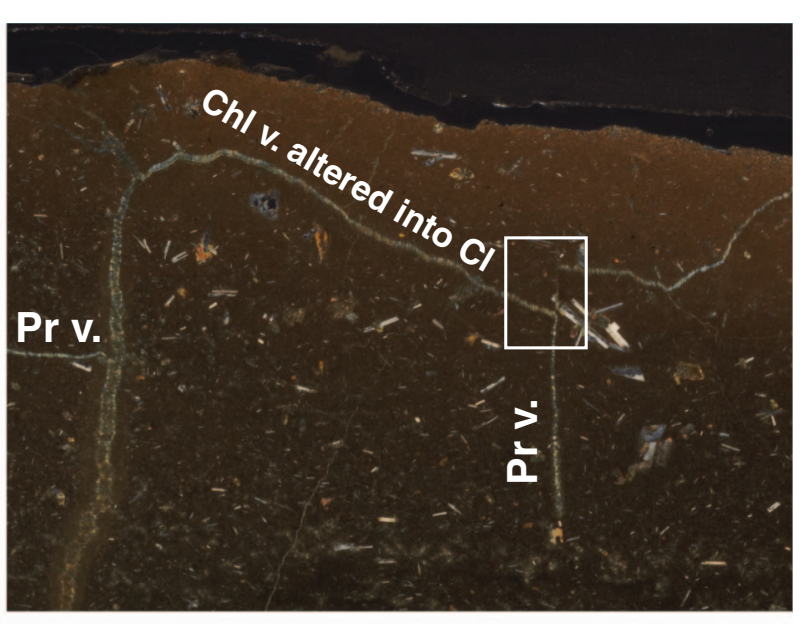

$1 \mathrm{~cm}$
B

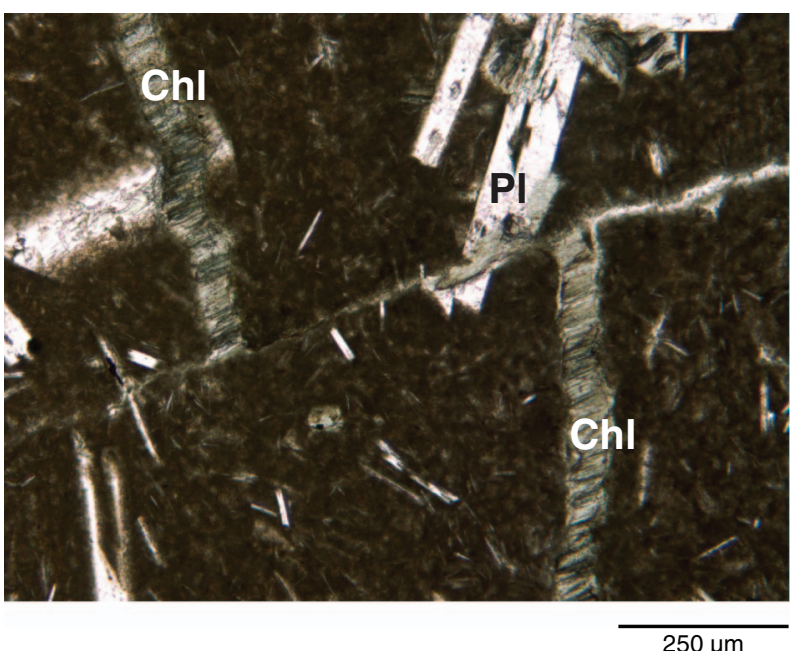


Figure F10. Basalt. A, B. Sample 345-U1415N-4R-1, 12-15 cm (Piece 3); plane-polarized light). (A) Basalt containing a few plagioclase phenocrysts hosted in a matrix with abundant plagioclase microlites. Groundmass decreases in size toward the altered areas in the top right indicating proximity to a chilled margin. (B) Moderate-strength flow orientation of plagioclase microlites. C. Olivine xenocryst in olivine-phyric basalt showing subgrains, which together with clumps of olivine crystals elsewhere in the sample suggests the olivine may be entrained from a partially crystallized magma chamber (Sample 345-U1415N-2R-1, 5-7 cm [Piece 1]; under crossed polars). D. Groundmass of moderately olivine-phyric basalt (Sample 345-U1415N-1R-1, 62-66 cm [Piece 12]; under crossed polars). Larger plagioclase crystals ( $>0.5 \mathrm{~mm}$ long) contain deformation twins (red arrow).

A

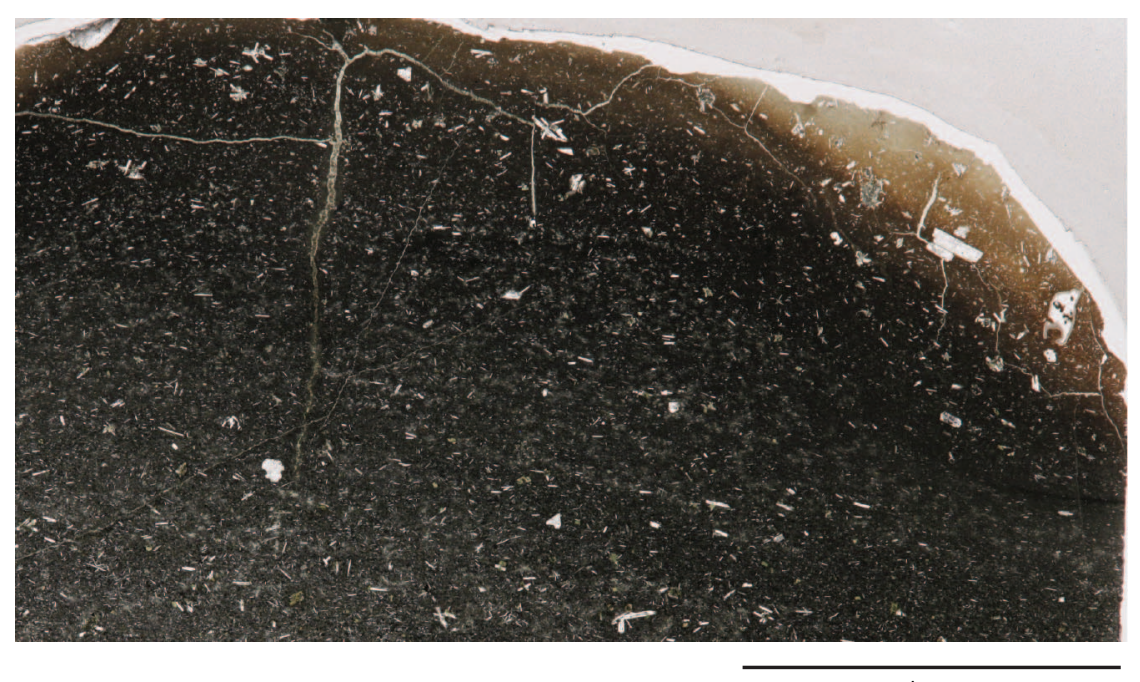

$1 \mathrm{~cm}$

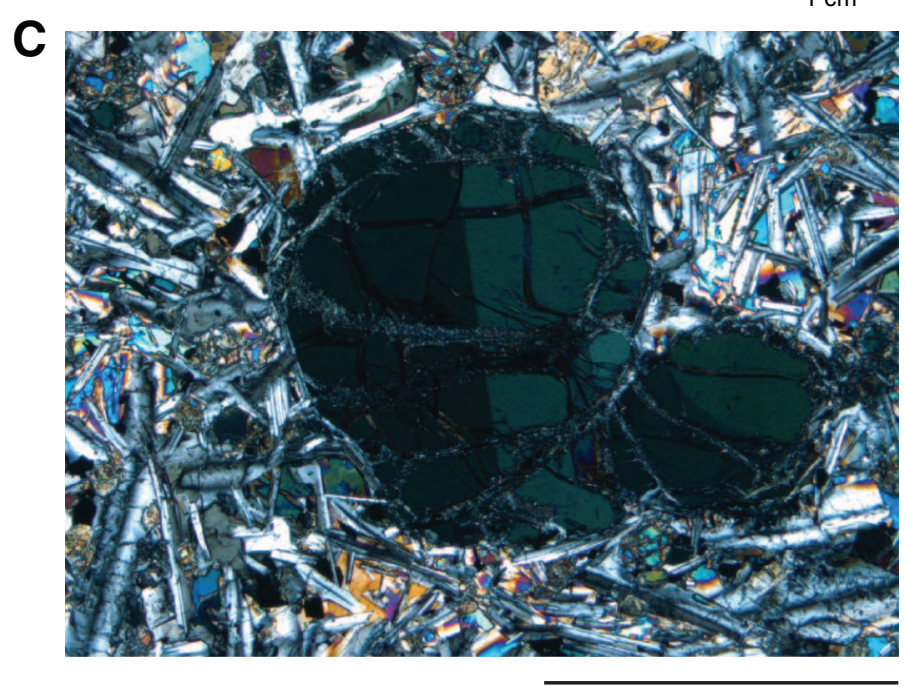

$1 \mathrm{~mm}$

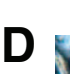

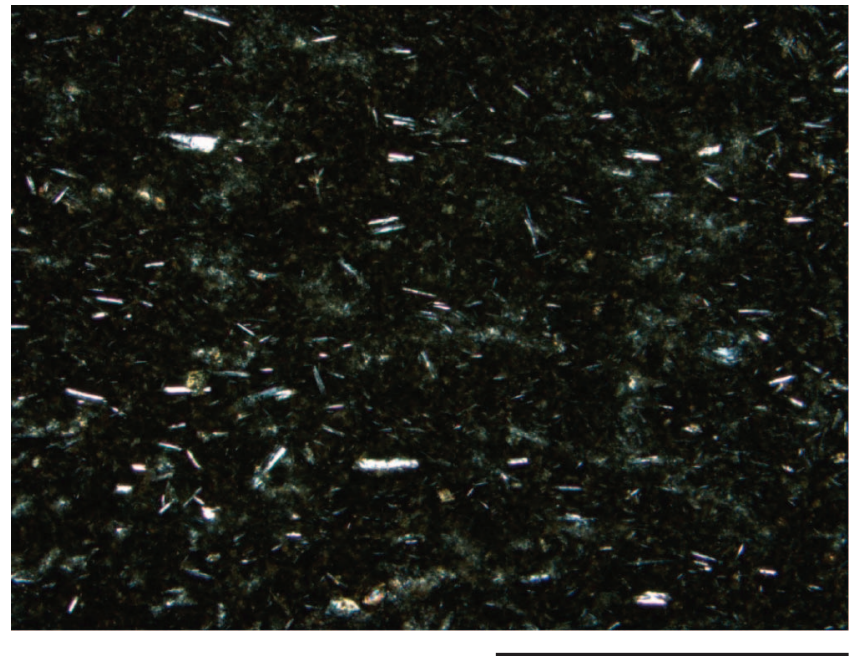

$1 \mathrm{~mm}$

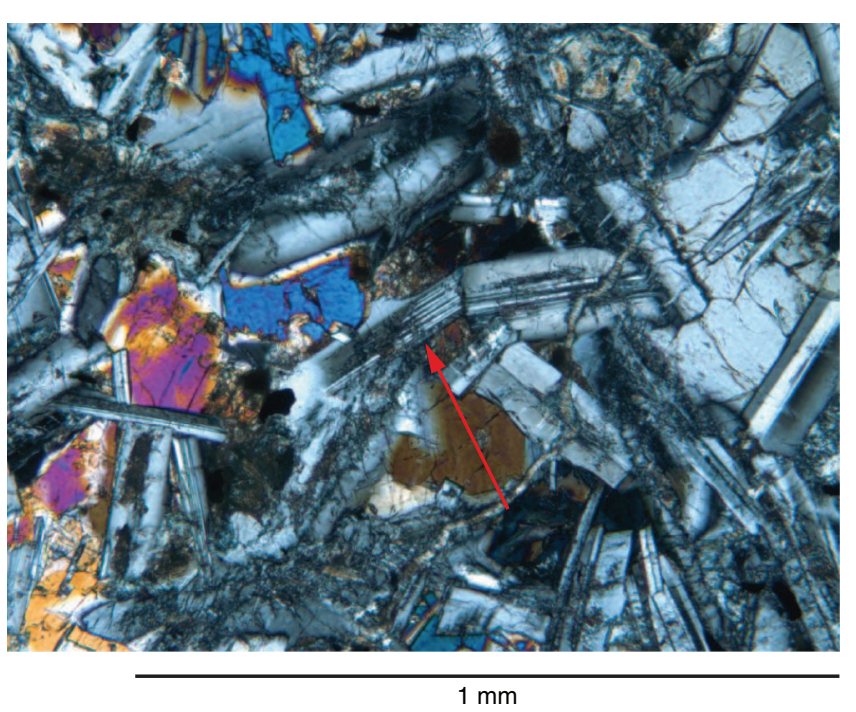


Figure F11. Subophitic dolerite (Sample 345-U1415N-4R-1, 52-54 cm [Piece 12]; under crossed polars). A. Dolerite contains a xenolith/enclave of an anorthositic troctolite $(2 \mathrm{~mm}$ mean grain size) to the right of the red dashed line. Red boxes (tick marks show upward direction) indicate locations of images in B and C. Red line indicates the orientation of the weak plagioclase foliation. B. Bent plagioclase crystal with deformation twins in the dolerite portion. C. Plagioclase crystals within the anorthositic troctolite xenolith showing subgrains (red arrow) and deformation twins.
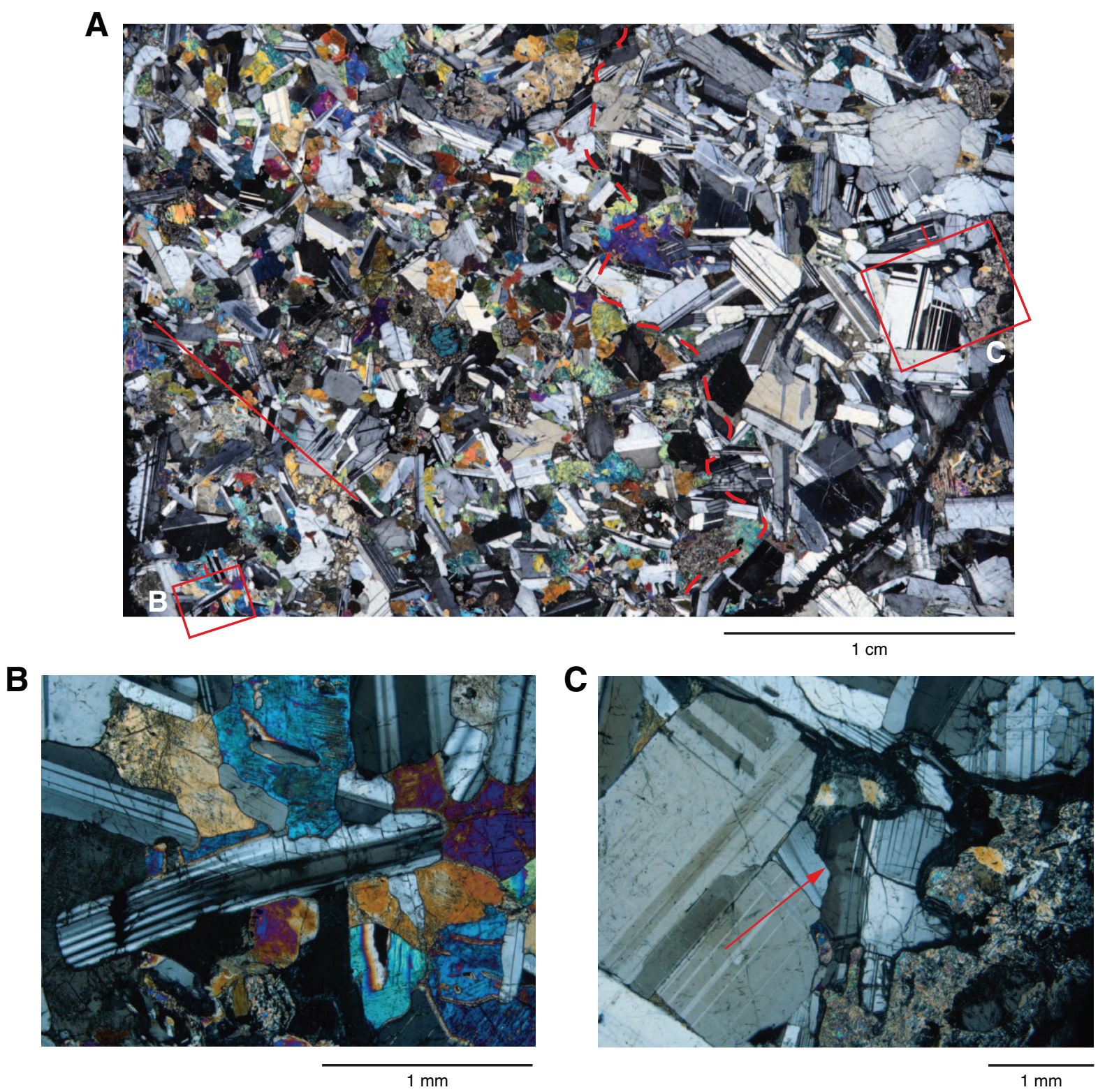
Figure F12. Total alkali $\left(\mathrm{Na}_{2} \mathrm{O}+\mathrm{K}_{2} \mathrm{O}\right)$ vs. silica $\left(\mathrm{SiO}_{2}\right)$ (after Le Bas et al., 1986), Hole U1415N. For comparison, basalt sampled along the East Pacific Rise (EPR) (www.earthchem.org/petdb/; 22 December 2012) during Ocean Drilling Program Leg 147 (Allan et al., 1996) and in Hole U1415J are shown. For the analyzed samples, total alkali was calculated by neglecting the $\mathrm{K}_{2} \mathrm{O}$ content because $\mathrm{K}_{2} \mathrm{O}$ content is very low $(<0.04 \mathrm{wt} \%)$.

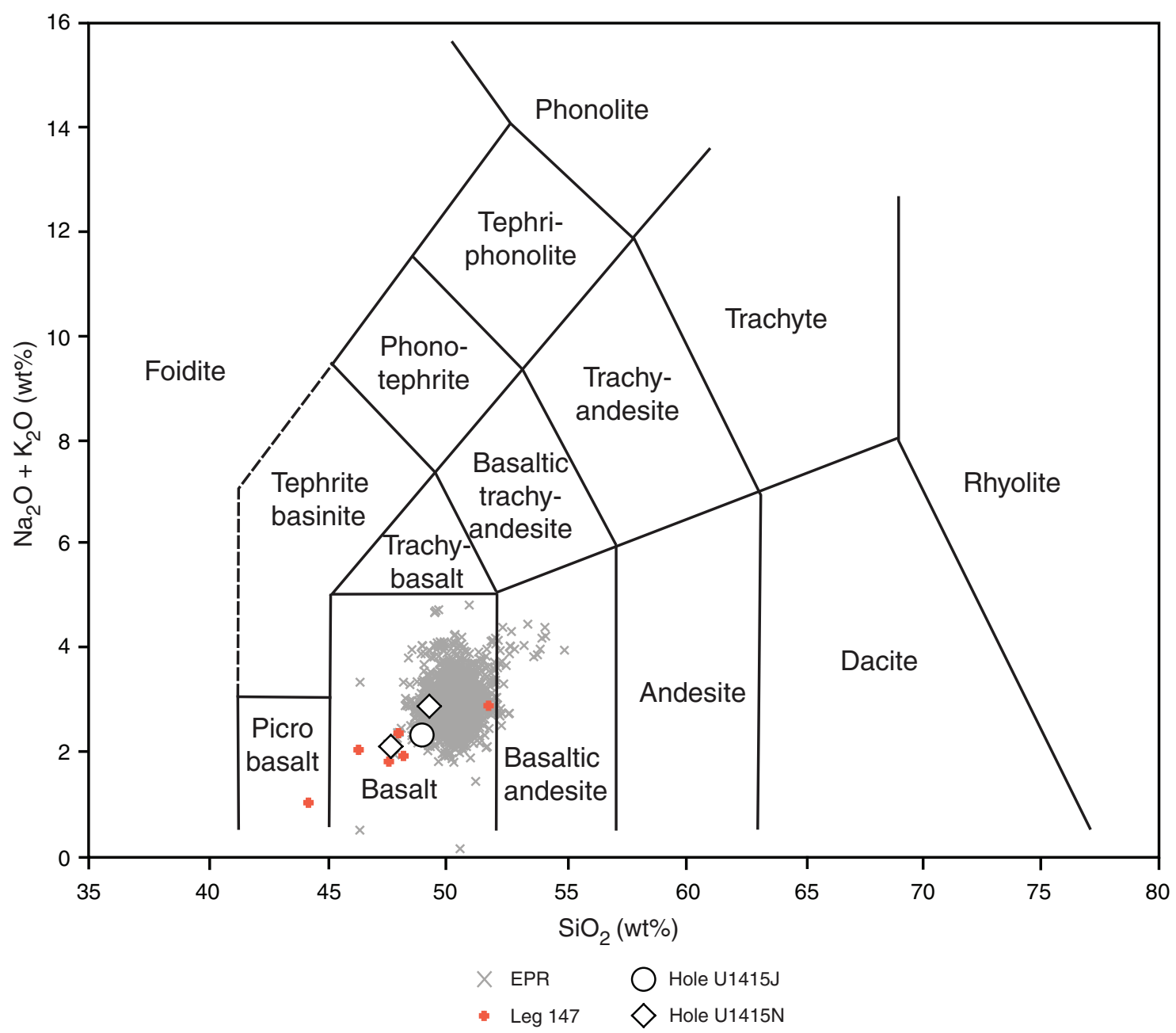


Figure F13. A-E. Composition of basalt, Hole U1415N. For comparison, basalt sampled along the East Pacific Rise (EPR) (www.earthchem.org/petdb/; 22 December 2012) during Ocean Drilling Program Leg 147 (Allan et al., 1996) and in Hole U1415J are shown.
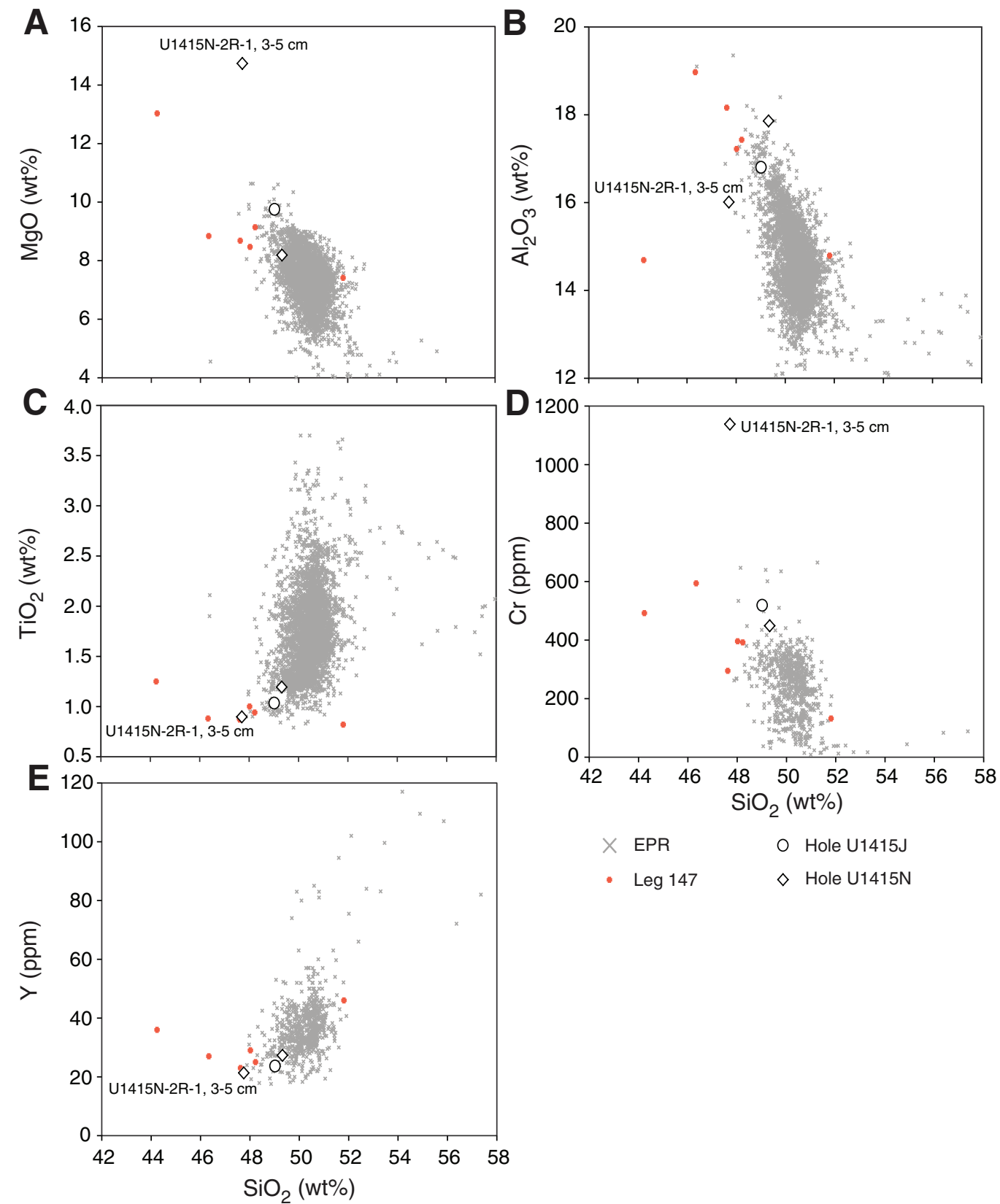

- Leg $147 \quad \diamond$ Hole U1415N 
Table T1. Operations summary, Holes U1415K-U1415N. (Continued on next page.)

Hole U1415K (failed attempt to establish reentry capability):

Latitude: $2^{\circ} 15.3307^{\prime} \mathrm{N}$

Longitude: $101^{\circ} 32.8527^{\prime} \mathrm{W}$

Time on site (h): 85.68 (0130 h, 16 January-1510 h, 19 January 2013)

Seafloor (drill pipe measurement below rig floor, $m$ DRF): 4698.4

Distance between rig floor and sea level $(\mathrm{m}): 11.3$

Water depth (drill pipe measurement from sea level, mbsl): 4687.1

Total penetration (drilling depth below seafloor, m DSF): 35.3

Total depth (drill pipe measurement from rig floor, $\mathrm{m} \mathrm{DRF):} 4733.7$

Total length of cored section $(\mathrm{m}): 0$

Total core recovered $(\mathrm{m}): 4.72$

Core recovery (\%): $0 \%$

Drilled Interval (m): 35.3

Total number of cores: 1 ghost

\begin{tabular}{|c|c|c|c|c|c|c|c|c|}
\hline \multirow[b]{2}{*}{ Core } & \multicolumn{2}{|c|}{ Depth (mbsf) } & \multirow{2}{*}{$\begin{array}{l}\text { Interval } \\
\text { cored } \\
(\mathrm{m})\end{array}$} & \multirow{2}{*}{$\begin{array}{l}\text { Core } \\
\text { recovered } \\
(\mathrm{m})\end{array}$} & \multirow{2}{*}{$\begin{array}{l}\text { Curated } \\
\text { length } \\
\text { (m) }\end{array}$} & \multirow[b]{2}{*}{$\begin{array}{l}\text { Recovery } \\
\text { (\%) }\end{array}$} & \multirow[b]{2}{*}{$\begin{array}{c}\text { Date } \\
(2013)\end{array}$} & \multirow[b]{2}{*}{$\begin{array}{l}\text { Time UTC } \\
\text { (h) }\end{array}$} \\
\hline & $\begin{array}{l}\text { Top of cored } \\
\text { interval }\end{array}$ & $\begin{array}{c}\text { Bottom of } \\
\text { cored Interval }\end{array}$ & & & & & & \\
\hline
\end{tabular}

345-U1415K-

$\begin{array}{ll}11 & 0.0 \\ 2 \mathrm{G} & 0.0\end{array}$

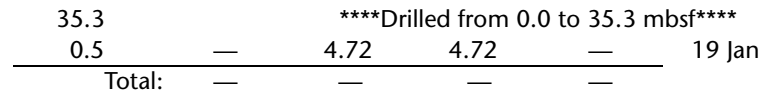

Hole U1415L (jet-in to 4 mbsf; no coring):

Latitude: $2^{\circ} 15.3300^{\prime} \mathrm{N}$

Longitude: $101^{\circ} 32.8041^{\prime} \mathrm{W}$

Time on site (h): 17.83 (1510 h, 19 January-0900 h, 20 January 2013)

Seafloor (drill pipe measurement below rig floor, $\mathrm{m} \mathrm{DRF):} 4686.0$

Distance between rig floor and sea level $(\mathrm{m}): 11.3$

Water depth (drill pipe measurement from sea level, mbsl): 4674.7

Total penetration (drilling depth below seafloor, $\mathrm{m} \mathrm{DSF}$ ): 4

Total depth (drill pipe measurement from rig floor, m DRF): 4690.0

Total length of cored section $(\mathrm{m}): 0$

Total core recovered $(\mathrm{m})$ : NA

Core recovery (\%): NA

Drilled Interval $(\mathrm{m}): 4$

Total number of cores: 0

Hole U1415M (failed attempt to establish reentry capability):

Latitude: $2^{\circ} 15.3304^{\prime} \mathrm{N}$

Longitude: $101^{\circ} 32.8040^{\prime} \mathrm{W}$

Time on site (h): $63.00 \mathrm{~h}$ (0900 h, 20 January-0000 h, 23 January 2013)

Seafloor (drill pipe measurement below rig floor, $m$ DRF): 4686.0

Distance between rig floor and sea level $(\mathrm{m}): 11.3$

Water depth (drill pipe measurement from sea level, mbsl): 4674.7

Total penetration (drilling depth below seafloor, $\mathrm{m} \mathrm{DSF}$ ): 4

Total depth (drill pipe measurement from rig floor, $\mathrm{m}$ DRF): 4690.0

Total length of cored section $(\mathrm{m}): 0$

Total core recovered $(\mathrm{m}): 5.87$

Core recovery (\%): 0

Drilled Interval (m): 25.9

Total number of cores: 1 ghost

\begin{tabular}{|c|c|c|c|c|c|c|c|c|}
\hline \multirow[b]{2}{*}{ Core } & \multicolumn{2}{|c|}{ Depth (mbsf) } & \multirow{2}{*}{$\begin{array}{c}\text { Interval } \\
\text { cored } \\
(\mathrm{m})\end{array}$} & \multirow{2}{*}{$\begin{array}{l}\text { Core } \\
\text { recovered } \\
(\mathrm{m})\end{array}$} & \multirow{2}{*}{$\begin{array}{l}\text { Curated } \\
\text { length } \\
(\mathrm{m})\end{array}$} & \multirow[b]{2}{*}{$\begin{array}{l}\text { Recovery } \\
\text { (\%) }\end{array}$} & \multirow[b]{2}{*}{$\begin{array}{c}\text { Date } \\
\text { (2013) }\end{array}$} & \multirow[b]{2}{*}{$\begin{array}{l}\text { Time UTC } \\
\text { (h) }\end{array}$} \\
\hline & $\begin{array}{l}\text { Top of cored } \\
\text { interval }\end{array}$ & $\begin{array}{l}\text { Bottom of } \\
\text { cored Interval }\end{array}$ & & & & & & \\
\hline \multicolumn{9}{|c|}{ 345-U1415M- } \\
\hline 11 & 0.0 & 25.9 & \multicolumn{6}{|c|}{ 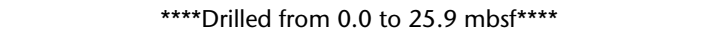 } \\
\hline $2 \mathrm{G}$ & 0.0 & 3.5 & - & 5.87 & 5.87 & - & 23 Jan & 0230 \\
\hline
\end{tabular}


Table-T1 (continued).

\begin{tabular}{|c|c|c|c|c|c|c|c|c|}
\hline $\begin{array}{c}\text { Hole U } \\
\text { Latitu } \\
\text { Longi } \\
\text { Time } \\
\text { Seaflo } \\
\text { Distar } \\
\text { Water } \\
\text { Total } \\
\text { Total } \\
\text { Total } \\
\text { Total } \\
\text { Core } \\
\text { Drille } \\
\text { Total }\end{array}$ & $\begin{array}{l}\text { 1415N (RCB c } \\
\text { de: } 2^{\circ} 15.3304 \\
\text { itude: } 101^{\circ} 32 \text {. } \\
\text { on site (h): } 49 \\
\text { or (drill pipe } r \\
\text { nce between r } \\
r \text { depth (drill } p \\
\text { penetration (d } \\
\text { depth (drill pip } \\
\text { length of core } \\
\text { core recoverec } \\
\text { recovery (\%): } \\
\text { d interval }(\mathrm{m}) \text { : } \\
\text { number of cor }\end{array}$ & $\begin{array}{l}\text { coring penetra } \\
4^{\prime} \mathrm{N} \\
8121^{\prime} \mathrm{W} \\
9.75(0000 \mathrm{~h}, 2 \\
\text { measurement b } \\
\text { rig floor and sea } \\
\text { pipe measureme } \\
\text { drilling depth b } \\
\text { ipe measureme } \\
\text { ed section }(\mathrm{m}) \text { : } \\
\mathrm{d}(\mathrm{m}): 1.56 \\
4 \\
0 \\
\text { res: } 4 \mathrm{RCB}, 1 \mathrm{gl}\end{array}$ & $\begin{array}{l}3 \text { January- } \\
\text { elow rig } f \\
\text { level }(m) \\
\text { ent from s } \\
\text { elow seafl } \\
\text { th from ris } \\
37\end{array}$ & $\begin{array}{l}145 \text { h, } 25 \text {, } \\
\text { oor, m DRF) } \\
11.3 \\
\text { a level, mbs } \\
\text { or, m DSF): } \\
\text { floor, m DR }\end{array}$ & $\begin{array}{l}\text { anuary } 201 \\
4686.5 \\
): 4675.2 \\
37.0 \\
\text { ): } 4723.5\end{array}$ & & & \\
\hline \multicolumn{3}{|c|}{ Depth (mbsf) } & \multirow{2}{*}{$\begin{array}{l}\text { Interval } \\
\text { cored } \\
(\mathrm{m})\end{array}$} & \multirow{2}{*}{$\begin{array}{l}\text { Core } \\
\text { recovered } \\
(\mathrm{m})\end{array}$} & \multirow{2}{*}{$\begin{array}{l}\text { Curated } \\
\text { length } \\
(\mathrm{m})\end{array}$} & \multirow[b]{2}{*}{$\begin{array}{c}\text { Recovery } \\
\text { (\%) }\end{array}$} & \multirow[b]{2}{*}{$\begin{array}{l}\text { Date } \\
(2013)\end{array}$} & \multirow[b]{2}{*}{$\begin{array}{c}\text { Time UTC } \\
\text { (h) }\end{array}$} \\
\hline Core & $\begin{array}{c}\text { Top of cored } \\
\text { interval }\end{array}$ & $\begin{array}{c}\text { Bottom of } \\
\text { cored Interval }\end{array}$ & & & & & & \\
\hline \multicolumn{9}{|c|}{ 345-U1415N- } \\
\hline $1 \mathrm{R}$ & 0.0 & 14.9 & 14.9 & 0.45 & 0.70 & 3 & 23 Jan & 2015 \\
\hline $2 \mathrm{R}$ & 14.9 & 18.9 & 4.0 & 0.15 & 0.22 & 4 & 24 Jan & 0145 \\
\hline $3 \mathrm{R}$ & 18.9 & 27.9 & 9.0 & 0.50 & 0.49 & 6 & 24 Jan & 1600 \\
\hline $4 \mathrm{R}$ & 27.9 & 37.0 & 9.1 & 0.46 & 0.57 & 5 & $24 \operatorname{Jan}$ & 2020 \\
\hline $5 G$ & 25.0 & 30.0 & - & 0.21 & 0.24 & - & 25 Jan & 0825 \\
\hline
\end{tabular}

Local ship time was UTC $-7 \mathrm{~h}$. Ghost core $(G)$ is not included in totals. DRF = drilling depth below rig floor, DSF = drilling depth below seafloor. $\mathrm{R}=$ rotary core barrel $(\mathrm{RCB})$ system, numeric core type $=$ drilled interval. $\mathrm{NA}=$ not applicable. $-=$ not calculated. 
Table T2. Details and explanations for thin sections with two igneous domains, Hole U1415N.

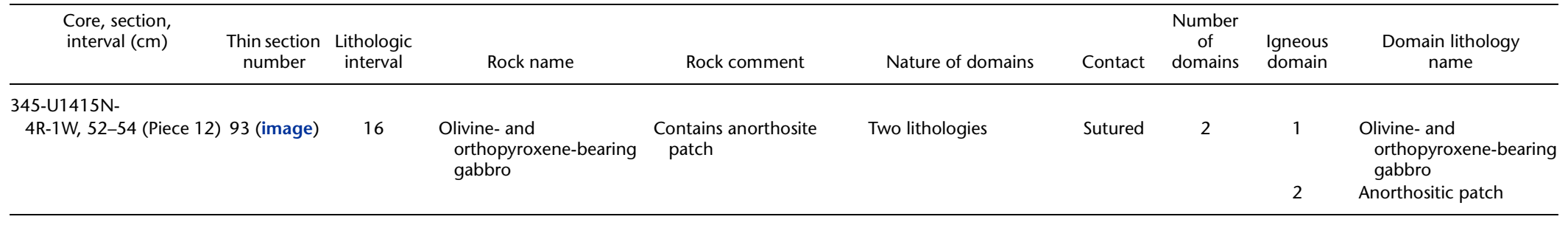

